\title{
Analyzing Stock Brokers' Trading Patterns: A Network Decomposition and Spatial Econometrics Approach
}

\author{
Juan Eberhard, ${ }^{1}$ Jaime F. Lavín $\mathbb{D}^{2},{ }^{2}$ Alejandro Montecinos-Pearce $\mathbb{D},{ }^{1}$ and José Arenas ${ }^{1}$ \\ ${ }^{1}$ Escuela de Negocios, Universidad Adolfo Ibáñez, Padre Hurtado 750, Viña del Mar, Chile \\ ${ }^{2}$ Escuela de Negocios, Universidad Adolfo Ibáñez, Diagonal Las Torres 2640, Peñalolén, Santiago, Chile \\ Correspondence should be addressed to Alejandro Montecinos-Pearce; amontecinospascal@gmail.com
}

Received 22 February 2019; Revised 10 June 2019; Accepted 23 June 2019; Published 25 July 2019

Guest Editor: Ahmet Sensoy

Copyright (c) 2019 Juan Eberhard et al. This is an open access article distributed under the Creative Commons Attribution License, which permits unrestricted use, distribution, and reproduction in any medium, provided the original work is properly cited.

\begin{abstract}
Using a unique data set with all the daily transactions from the Santiago Stock Exchange, we develop a novel methodology that combines a network decomposition with a spatial econometrics technique to study how brokers' characteristics and trading decisions may affect the stock market return. We present suggestive evidence of a mechanism by which structural changes of the transaction network between brokers affect the aggregate returns of the stock market. We find that brokers tend to trade with counterparties with dissimilar intraday selling volume when market return significantly increases. Moreover, brokers with a research department tend to sell to brokers without a research department when the market experiences a considerable increase of its return. From the financial perspective, these results highlight new ways in which intermediaries may affect market equilibrium and the efficiency of the market.
\end{abstract}

\section{Introduction}

Financial institutions are relevant to the performance of capital markets. Every day companies and investors interact with financial intermediaries (FIs) such as banks, insurance companies, pension funds, mutual funds, and brokerage firms. The financial management of investors involves the existence of FIs [1], which form transaction networks while exercising their functions. It is possible that the dynamic behavior of these networks, studied by Sensoy and Tabak [2] and Guerra and others [3], affects market returns through the specific trading matches between different types of brokers. The behavior of some FIs such as banks [4-7] and mutual and pension funds [8] have been studied extensively in the financial literature. ${ }^{1}$ However, the role of brokerage firms on stock market performance has been scarcely analyzed. This knowledge gap is particularly relevant in the context of the undergoing demutualization process of stock markets in developing economies. ${ }^{2}$ The increase of the heterogeneity across brokerage firms, generated by the latter process, is likely to increase the complexity of the trading interactions within the stock markets of emerging economies. Thus, from a policy perspective, advancing our knowledge about these market interplays is critical in keeping regulation up to date, and consequently, from a financial point of view, it enhances the stock markets' efficiency. ${ }^{3}$

In this paper, we contribute to improve the understanding of the role of brokerage firms in a context of underdeveloped stock markets. Namely, we study the correlation between the patterns of the transaction network of brokers with specific typologies in an emerging economy during considerable increases of the market's return. The Santiago Stock Exchange (SSE) provides adequate conditions to study how the complexity of the trading interactions between FIs affects the market's efficiency. This occurs for several reasons. First, the data from the SSE allows the construction and studying a subset of financial transaction networks through time, mostly ignored by the literature. Second, the SSE is one of the most important markets of the Integrated Latin American Market agreement (Mercado Integrado Latinoamericano; MILA) [9]. Third, the SSE is the leader in the Chilean stock market with $92.9 \%$ of the total market share. Fourth, the SSE broker transaction network captures the bulk of stock purchase and sale decisions of institutional investors and the main 
family offices and retail investors in Chile. Finally, Chile is a developing country with medium-level financial development. Thus, we expect our findings to provide a helpful guide for private stakeholders, policymakers, regulators, and market participants in stocks markets belonging to emerging economies.

In this emerging market context, brokers may face liquidity constraints generated by capital restrictions that prevent them from executing all the transaction orders they receive [10-12], and since there is a positive relationship between volumes traded and price changes [13-16], we should expect that, during relevant variations in market prices, there would be a positive assortative matching in traded volume between selling and buying brokers. That is, brokers that receive large orders look for matches with brokers that can absorb these transactions. In this sense, the latter pattern raises the question of whether positive assortative matching in selling volumes between brokers affects the probability of a large increase in the stock market's return.

Therefore, the main hypothesis of our paper (H1) is that brokers tend to trade with counterparties with similar selling volume per trading counterparty when the return of the market significantly increases. The recent literature on brokerage firms suggests the existence of frictions in the stock market associated with brokers' typologies and induced actions, which contribute to the formation of the brokers' transaction network. In particular, the latter literature suggests that having analysts organized in a research department, possessing large or small equity (size), and holding various complementary services (economies of scope) are important broker (brokerage firm) typologies that can affect the performance of a stock market.

Thus, we focus our analysis on the relation between these typologies and the aggregate return of an emerging economy's stock market. More specifically, we test whether there exists evidence of (H2.a), a negative correlation between positive assortative matching of intraday mean volume in the transaction subnetwork of brokers with a specific type "A", and a significant increase of the IPSA return; whether there exists evidence of (H2.b), a positive correlation between negative assortative matching of intraday mean volume in the transaction subnetwork of brokers with specific type " $\mathrm{A}$ ", and a significant increase of the IPSA return; and whether there exists evidence of (H2.c), a positive correlation between positive (and negative) assortative matching of intraday mean volume in the transaction subnetwork between brokers with and without specific type " $A$ ", and a significant increase of the IPSA return ${ }^{4}$ (see Section 5 for a detailed explanation of the difference between $\mathrm{H} 2$.a and H2.b).

To study the above, we compare the results from the whole transaction network with results associated with specific subnetworks defined by relevant brokers' types. Our methodology is flexible to accommodate the study of how the presence of organized analysts, the presence of brokers' size, and the presence of economies of scope or whether brokerage firms do proprietary trading may affect the election among trading counterparties, producing specific patterns in the brokers' transaction network. ${ }^{5}$ Using methods that combine a network decomposition and spatial statistical analysis, we isolate the effect of exogenous brokers' characteristics on the selection of trading counterparties in the brokers' transaction network. For interpretational purposes we represent the brokers' transaction network in terms of sales. ${ }^{6}$ We construct these networks using data provided by the SSE that covers every daily stock transaction from 2006 until 2015. In addition, we completed our dataset with public information provided by the Financial Market Commission (www.cmfchile.cl, is the Chilean equivalent of the SEC for the USA) and Bloomberg (www.bloomberg.com). Based on the latter information, we used the SSE IPSA price index to compute significant rises of the market return considering various magnitudes of increase as thresholds.

The social networks literature refers to the presence of positive assortative matching, i.e. positive spatial dependence, as homophily [17]. This phenomenon refers to the aggregate behavior in which individuals have a tendency to establish relations with those who have a similar type. However, brokers may tend to sell their volume to brokers who are opposite to them. We refer to this tendency to trade with the complement or opposite of oneself as heterophily. This latter pattern would emerge if brokers tend to sell to other brokers that strongly differ from themselves. For instance, when the typology is dichotomic, heterophily means that a broker of type " $\mathrm{A}$ " tends to sell to individuals of type "not-A".

To study the presence of homophily or heterophily in average volume traded by brokers in their daily transaction network, we use the Moran's I test for spatial dependence [18], where the individual broker's intraday average trading volume is the dependent variable in the test. ${ }^{7}$ However, the brokerage literature suggest that a broker's intraday average selling volume may not be solely determined by her preference to trade with brokers sharing similar selling volume. Thus, stock market brokers may have two possible sources of average selling volume associated homophily (heterophily): First, the tendency to sell to brokers who sell similar intraday average volume. Second, the tendency to sell to brokers that share a common exogenous type, such as providing investment banking services or having analysts organized in a research department. We denote the first category of homophilic pattern as endogenous homophily, and the second variety of homophily as exogenous homophily, because the brokers' types are not affected by daily trading decisions. Thus, positive spatial dependency signals endogenous homophily and negative spatial dependency signals endogenous heterophily.

Because we represent the brokers' transaction network in terms of sales, a homophilic pattern implies that large volumes of shares tend to be bought by brokers that are prone to selling behavior. Thus, intraday positive spatial dependency (endogenous homophily) in large volume transaction networks suggests that in the market most of the drivers are brokers with a selling attitude, then the intraday market return would fall. In this situation, stocks at an aggregate level resemble a hot potato that only a few brokers are asked to buy and which the majority of brokers continue to sell. ${ }^{8} \mathrm{On}$ the contrary, a negative spatial dependence in a large volume transaction network indicates that brokers are consistently 
selling to brokers who tend to sell smaller average volumes, i.e., brokers who tend to keep most of their buys.

Following several authors [10, 11, 19], we use four exogenous typologies to define the aforementioned set of subnetworks: (a) proprietary trading activity, (b) having a research department, (c) providing investment banking services, and (d) having large equity. ${ }^{9}$ Thus, to study the mechanism that generates endogenous homophily, we partition the whole brokers' transaction network into specific nonoverlapping subnetworks to analyze the presence of spatial dependency (also using Moran's I). To study the relation between homophily/heterophily (endogenous or exogenous) and significant increases of the market return, we use a Probit estimation.

Our distinction between homophily and heterophily plays a key role in our analysis because the absence of one does not imply the other. Thus, we study the aforementioned Probit models independently for both an indicator of positive and negative spatial dependency. This methodology enables us to study whether, during episodes of a significant increase of the IPSA return (IPSA jumps), brokers exhibit homophilic or heterophilic trading patterns and how the latter occurs. Namely, we distinguish endogenous homophilic patterns from exogenous homophilic patterns. The latter allows us to circumscribe the subset of exogenous brokers' typologies that may initiate the trading mechanism which provokes a significant increase of the IPSA return.

Our main results indicate that the presence of endogenous homophily is negatively associated with episodes of significant increases of the IPSA return. When partitioning the brokers into groups, as previously explained, we find that the aggregated pattern mostly persists when the set of brokers is partitioned considering whether a broker has a research department, but is not present for the other partitions considered by the literature. More interestingly, the research department typology suggests the presence of exogenous heterophily during events of large increases of the IPSA return. That is, brokers with research departments tend to sell to brokers without research departments when an episode of a significant increase in the IPSA return occurs.

The rest of this paper is structured as follows. In Section 2 we discuss the related literature, and in Section 3 we describe our data. Then, the fourth section characterizes the Chilean brokerage industry. In Section 5, we present the methodology in depth. In Section 6, we present the results of our analysis, and finally, in the seventh section, we provide our conclusions and extensions.

\section{Related Literature}

Acting as facilitators for the trading of financial assets, brokerage firms can carry out a range of different activities, including underwriting new securities, making markets for seasoned securities and providing services to customers in their financing and investment activities [20]. The current literature on the implications of the FIs' and brokers' actions has solely focused on developed financial markets; however, in both developing and emerging markets, a deeper understanding of the impact of brokers on the operation of these markets is still required. This need stems from the fact that underdeveloped markets present a level of market efficiency that is lower than in developed countries [21]. Eberhard, Lavín, and Montecinos-Pearce [22] find evidence that structural changes in the brokers' transaction network are associated with positive increases of the stock market return in an emerging economy.

The standard analysis of financial markets assumes that, regardless of their types, the FIs' actions do not affect the value of financial assets. The latter occurs because asset valuation models focus exclusively on the risk and return relationship of the assets made by investors, and not on the process of financial intermediation [1]. Nevertheless and regardless of whether investors use their money to buy assets directly or acquire mutual funds to invest indirectly in the stock market, the final transaction of the purchase and sale of the asset is delegated to a broker. More specifically, in capital markets, there is a financial intermediation process in which assets are not transformed as in the case of banking. Namely, a deposit is transformed into a credit, but their ownership is transferred between an investor that buys and another investor that sells in transactions executed by brokers [23]. Thus, it appears that transactions between brokers should not affect the return of the capital assets they trade. In contrast to the latter approach, the financial market microstructure literature indicates that the structure of financial markets generates frictions that influence the returns of financial assets. Easley and O'Hara [13] argue that these frictions affect transaction costs and returns. Moreover, the causes of these frictions can be traced back to the brokers executing the transactions. These frictions are associated with fixed costs, size, fees, and factors that stem from the characteristics of the traded assets such as payment, liquidity, and volatility, among others. Traditionally, when a firm decides to raise external financing by issuing shares or bonds, it contracts a broker, who, in exchange for her services, receives a fee for placing the instrument in the market. However, brokers provide a wider and more complex scope of services than just executing orders from investors. More recently, these FIs are dedicated to traditional activities such as trade orders execution, but also perform economic analysis and business recommendations and investment banking tasks. ${ }^{10}$

Moreover, the business context in which brokers perform these tasks has changed in recent years. One source of this change is the profound technological transformations of the financial markets. This massive change has produced a dramatic evolution in the way trading is conducted, thereby inducing greater competitive pressure on the incumbent brokers in the industry [24]. Boehmer, Jennings, and Wei [25] found that clients' buying and selling order decisions are associated with execution quality. Namely, those brokers with low costs and fast execution receive more orders. Consequently, the brokerage industry faces pressures for lower fees and high-quality trade execution. Similarly, the urgency for increasing the brokerage firms' profitability exerts greater pressure on brokers to sustain revenues by fostering investment banking activities and increasing their own capital in proprietary trading [26]. ${ }^{11}$ These changes in conjunction 
with the frictions mentioned above prompt optimizing agents in financial markets to exhibit specific behavioral patterns. We argue that the existence of these patterns strongly suggests mechanisms through which financial frictions affect the markets' returns.

The increasing complexity of the financial markets documented by Goldstein and others [26], suggests that specific broker's typologies play a role in the emergence of the aforementioned behavioral patterns. For example, Hagerty and McDonald [10] indicate that, in a market with asymmetric information, informed traders earn a profit at the expense of uninformed traders, and they face an incentive to serve as counterparty to the trade rather than just as a brokerage conduit. There is also evidence of frictions related to the existence of how different types of brokers affect the equilibrium of the stock market [27].

Recent studies on individual brokerage firms have not only analyzed the role of analysts on brokerage firms' profits, but also, the existence and effects of economies of scale and scope, and the effects of size on the efficiency of these FIs. Regarding trade execution, brokers face restrictions in accepting unlimited numbers of orders since, on the one hand, they face capital requirements, and on the other hand, they have limited capital [10]. In this regard, Demirbag and others [11] explore the efficiency of securities firms in Turkey. They indicate that knowledge, assets, and financial capabilities are relevant factors on the viability of these intermediaries. They find that bank affiliation, foreign ownership, and size positively influence the efficiency of brokers. In the same spirit, Lee and others [12] find that larger brokers in Korea enjoy economies of scale and scope. In particular, greater economies of scale are present in larger firms.

Consequently and according to several authors $[10,11,19]$, the exogenous typologies of brokers that we consider in our analysis are brokerage firms with (a) proprietary trading activity, (b) a research department, (c) investment banking services, and (d) large equity.

\section{Main Data Sources}

We use all of the available data from the daily stock transactions conducted by stock brokers at the SSE for the period 2006-2015. The dataset provided in anonymized form, with no association between the broker's name and their transactions, includes the following information: day of transaction, instrument traded, type of operation, units exchanged, purchase price, and the identification of brokers involved in buying and selling. We use the latter data to construct the daily directed transaction network based on sales for the Chilean equity market following Eberhard and others [22]. ${ }^{12}$ We consider this brokers' transaction network, henceforth transaction network, as the space in which we apply a spatial econometrics technique to detect spatial dependence. Following the latter authors, we also consider standard financial variables to capture possible factors that may affect the IPSA return. Finally, we construct the time series of significant positive increases in the IPSA return; henceforth IPSA jumps, considering moving annual periods.

\section{The Chilean Stock Market Brokerage Industry}

In Chile, stock brokerage focuses on the intermediation of stocks, money market, and fixed income instruments, representing $80.8 \%$ of the total traded during 2015 . The stock transactions averaged MMUSD 50,641 per year from 20062015. These transactions were conducted by an average of 32 brokers per year, who traded on average MMUSD 1,594 per broker.

There are four types of brokers in this industry: subsidiaries of commercial banks, subsidiaries of investment banks, those related to insurance companies, and traditional brokers. According to figures published by the SSE, as of December 2015, brokers linked to investment and commercial banks represented $87.5 \%$ of the total amount traded and $75.4 \%$ of the industry's total equity. In terms of equity, commercial bank brokers are the most important $(54.9 \%$ of total equity). In terms of volume traded, investment bank brokers are the largest brokers (51\% of the total volume). The largest number of brokers in the market consists of traditional brokers and those belonging to commercial banks with $63 \%$ joint market share.

In 2015 , there were $2,695,141$ stock purchase/sale transactions for an average value of MMUSD 21,932. These transactions include those transactions conducted on behalf of third parties ( $88 \%$ of the total) and on their proprietary accounts and related transactions (12\% of the total). Despite the changes experienced in this market in recent years, the previous figures have stabilized around $10 \%$ for transactions on their proprietary accounts and $90 \%$ for third party operations. Moreover, according to SSE figures, $71.5 \%$ of the total traded is done by local investors.

The structure of the stock brokerage industry in Chile is stable over time, which is similar to stock markets in developed countries as found by Hayes and others [28] and Anand and Galetovic [29]. Table 1 shows the market share of the Top 10 brokers and the remaining $90 \%$. Between 2006 and 2015, 80.2\% of the total traded was executed by only 10 stockbrokers, which on average represent $32.1 \%$ of the total brokers operating in Chile in that same period. $^{13}$

\section{Methodology}

As indicated previously, our objective is to study the possible correlation between the tendency to trade with brokers that sell similar volumes as their counterparts (endogenous homophily) and significant increases of the IPSA return (jumps). Our first step is to study the spatial dependence of the average volume sold by each broker in the daily transaction network in the SSE. Then, we isolate the effect of exogenous homophily on the trading counterparty decision of brokers, i.e., endogenous homophily (heterophily), on large increases of the market return. For this, we define three subnetworks of the transaction network that do not overlap. These subnetworks are the subnetwork of nodes of type " $\mathrm{A}$ "14 and the subnetwork of nodes with type "not- $\mathrm{A}$ " and the 
TABLE 1: Summary of stockbrokers (2006-2015).

\begin{tabular}{|c|c|c|c|c|}
\hline \multirow{2}{*}{ Year } & \multicolumn{2}{|c|}{ Top 10 Stockbrokers } & \multicolumn{2}{|c|}{ Non-Top 10 Stockbrokers } \\
\hline & $\%$ Traded & $\%$ Repr. & $\%$ Traded & \% Repr \\
\hline 2006 & $83.5 \%$ & $29.4 \%$ & $16.5 \%$ & $70.6 \%$ \\
\hline 2007 & $77.7 \%$ & $30.3 \%$ & $22.3 \%$ & $69.7 \%$ \\
\hline 2008 & $82.0 \%$ & $32.3 \%$ & $18.0 \%$ & $67.7 \%$ \\
\hline 2009 & $80.7 \%$ & $32.3 \%$ & $19.3 \%$ & $67.7 \%$ \\
\hline 2010 & $81.9 \%$ & $32.3 \%$ & $18.1 \%$ & $67.7 \%$ \\
\hline 2011 & $83.6 \%$ & $31.3 \%$ & $16.4 \%$ & $68.8 \%$ \\
\hline 2012 & $77.3 \%$ & $30.3 \%$ & $22.7 \%$ & $69.7 \%$ \\
\hline 2013 & $75.9 \%$ & $32.3 \%$ & $24.1 \%$ & $67.7 \%$ \\
\hline 2014 & $78.9 \%$ & $33.3 \%$ & $21.1 \%$ & $66.7 \%$ \\
\hline 2015 & $80.3 \%$ & $37.0 \%$ & $19.7 \%$ & $63.0 \%$ \\
\hline Average & $80.2 \%$ & $32.1 \%$ & $19.8 \%$ & $67.9 \%$ \\
\hline
\end{tabular}

${ }^{1}$ Own elaboration based on public information.

bipartite subnetwork of transactions between the brokers of the two opposite types. ${ }^{15}$

It should be noted that the IPSA jumps are sparse in time. For this reason and because the occurrence of an IPSA jump is a dichotomous event, we estimate a Probit to study if changes in the network's matching patterns are correlated with the IPSA jumps. Specifically, we studied the correlations for 11 different magnitudes of IPSA jumps: increases that range from 1 standard deviation with increments of 0.1 standard deviations to reach increases of the IPSA return of 2 standard deviations. ${ }^{16}$ That is, the Probit for the first case is estimated for the series that contains a 1 on the days where the IPSA returns exceed 1 standard deviation, and 0 if the IPSA returns do not exceed it. Similarly, in the second case, the series takes on values 1 when the changes in the IPSA return exceed 1.1 standard deviations, and so forth. In the latter class of models, the indicator of a significant increase of the market return is the dependent variable, and an indicator of spatial dependency (positive for endogenous homophily and negative for endogenous heterophily) is the independent variable of interest.

Another important element to consider is the transactions considered to build the networks in study. As in Eberhard and others [22], we study the correlation for networks constructed for different thresholds of the total amounts traded between brokers (volume deciles are used as thresholds). Decile 10 corresponds to $100 \%$ of the transactions, while decile 1 only contains the top $10 \%$ of the transaction volume. In this way, we analyze our hypotheses for different magnitudes of transactions: from smaller to larger and for different intensities of the increase in the IPSA return. This allows us to evaluate how considering smaller transaction flows, which potentially incorporate more volatility with respect to financial market movements, affects the correlation between jumps in the IPSA return with spatial dependence. At the same time, we can study whether the correlation between IPSA jumps and spatial dependence is stronger depending on the intensity of the IPSA jump.
Following Eberhard and others [22], the Probit estimation will be controlled by financial variables that may affect the IPSA returns. In particular, we control for the variation of the following variables: oil price, dollar price, VIX index, emerging markets index, copper price, 5 -year credit default swaps, and the S\&P 500 stock index. Additionally, controls are included by month and year to isolate seasonal effects in specific months and years. In order to simplify the presentation of results and to facilitate the visualization of the patterns that emerge when comparing the previous regressions, the results of the regressions for the controls are not presented; however, they are available for interested readers. Accordingly, figures of the results will focus on showing the significance of the spatial dependence variable for the aforementioned Probit models. Once the existence of positive and negative spatial dependence is assessed using the Moran I test, we generate an indicator variable for positive spatial dependence or homophily and an indicator variable for negative dependence correlation or heterophily. These variables are constructed for the networks defined for the 10 different jump thresholds in the IPSA return.

In order to study (H1), i.e., brokers that tend to trade with counterparties with similar selling volume per trading counterparty when the return of the market significantly increases, we first consider the entire transaction network as the space over which we conduct the Moran I test. Second, we study the Probit model previously described. A statistically significant coefficient on the indicator for spatial dependency may indicate that a potential homophilic (or heterophilic) behavior may influence the aggregate stock market returns.

Accordingly, the presence of positive spatial dependence in the transaction network indicates that brokers with a large sold average volume within the day tend to trade with other brokers that sell large average volumes within the day. ${ }^{17}$ That is, when there is positive spatial dependence, brokers sell to similar counterparts, in terms of sold intraday average volume. Because the brokers' transaction network identifies which brokers sell to which, a homophilic pattern in large 
volume transaction networks (deciles 1, 2, or 3) is consistent with the tendency to have large volumes being sold to brokers that intend to sell those volumes as well. If the latter is the case, then endogenous homophily would reduce the likelihood of an IPSA jump. The latter occurs, because if most brokers receive sell order that involve large volumes (transaction networks for the deciles 1 through 4 ), then only a minority of brokers are on the other side of the market, i.e., buying large volumes of stocks. In such a market context, the stocks resemble a hot potato. The opposite case emerges when the brokers' transactions follow an endogenous heterophilic pattern. Such a pattern suggests that brokers that sell large volumes tend to do so to brokers that do not sell large volumes, but could eventually buy large volumes. This suggests that the stocks are not a hot potato, but on the contrary, they are assets acquired to obtain an economic benefit. Thus, it should be more likely to observe an IPSA jump. Therefore, it is necessary to ask: what causes the brokers' tendency to trade with similar/dissimilar counterparties? That is to say, can one delve into understanding the possible mechanism through which the matching pattern between brokers arises in the presence of an IPSA jump. We address this question in considering the exogenous typologies found in the literature: (a) proprietary trading activity, (b) having a research department, (c) providing investment banking services, and (d) having large equity. ${ }^{18}$ Accordingly, the analysis necessary to study the possible causes of endogenous homophily (heterophily) requires two key steps: decompose the set of brokers according to the mentioned criteria, and then calculate the spatial dependence indicators and run the Probit models.

First, we decompose the transaction network based on the brokers' exogenous typologies in order to capture the effect of exogenous homophily or heterophily on the spatial dependency of the average volume traded in each transaction subnetwork. ${ }^{19}$ The classification of brokers according to an exogenous typology allows us to study the brokers' choice under two dimensions simultaneously: one endogenous (volume traded) and one exogenous (e.g., investment banking services). Second, we calculate the spatial correlation indicators previously described in each of the subnetworks defined by the aforementioned attributes; ${ }^{20}$ and analogously in studying the complete network, we use the Probit model previously described to study the correlation between IPSA jumps and pattern of matches of trading counterparties in each subnetwork. That is, we will study if, for example, within the group of brokers with a research department, we observe that they trade with brokers with similar volume traded or not. These Probit models allow us to study the following hypotheses according to a specific type: ${ }^{21}$

(1) H2.a The coefficient of the positive spatial dependence indicator of the daily average volume sold in the type "A" broker subnetwork is negative and significant.

(2) H2.b The coefficient of the negative spatial dependence indicator of the daily volume traded in the type "A" broker subnetwork is positive and significant.
(3) H2.c The coefficient of the negative spatial dependence indicator of the daily volume traded in the subnetwork between type "A" and type "not-A" brokers is positive and significant.

In the presence of an IPSA jump, the absence of systematic positive assortative matching in daily average volume sold does not imply that there is systematic negative assortative matching in the same variable because there is not a necessity of any matching pattern. Thus, we need to test both hypotheses H2.a and H2.b. In addition, our working hypotheses do not have any implications regarding the way in which brokers, for example, without a research department trade among each other. Thus, we do not focus on studying specific patterns in the type "not-A" subnetworks.

\section{Results}

Figure 1 shows the Probit model regression results for IPSA jumps of different intensities (columns 2-12) and for different total volume thresholds traded daily between brokers (rows 2-11). Each cell in Figure 1 contains the coefficient associated with the spatial dependence indicator for positive spatial dependence ${ }^{23}$ and the corresponding $p$-value. A yellow cell indicates that the estimator of the coefficient in the Probit is negative, while a blue cell indicates that the coefficient is positive. Additionally, if the cell color is lighter, that is light yellow or light blue, then the coefficient is not significant, while darker colored cells are reserved for significant coefficients. ${ }^{24}$ This color coding allows us to easily identify patterns across the many regressions presented. In Figure 1, the vast majority of coefficients are negative and not significant. This suggests that the presence of positive spatial dependence does not affect the likelihood of an IPSA jump for most thresholds. That is, apparently there is no evidence of a specific pattern when intermediaries decide to whom they will sell. This fact would be consistent with the notion derived from the efficient market theory that FIs do not matter as pointed out by Allen [1]. However, Figure 1 reveals the presence of a pattern when we focus on (daily) networks built exclusively with large aggregate volumes traded between brokers, particularly the first, second, and third deciles. ${ }^{25}$ In these cases, most coefficients are significant and they show a clear tendency to increase in absolute value when the intensity of the IPSA jumps increases. This is evidence that the importance of positive spatial dependence grows with the size of the increase in the IPSA return.

The coefficients' negative sign and their significance indicate that when brokers sell to intermediaries with similar average daily sold volume, that is, when there is endogenous homophily (positive spatial dependence), the probability of an IPSA jump decreases. Therefore, if we focus on large volume transaction networks, this correlation between endogenous homophily and IPSA jumps is consistent with most brokers executing orders to sell stocks. This behavior is consistent with a bear market. The preceding leads us to ask the following question to circumscribe the nature of the relation between an endogenous homophilic trading pattern between brokers and the stock market's return: Does 
Size of the IPSA jump used in the Probit Regression

\begin{tabular}{|c|c|c|c|c|c|c|c|c|c|c|c|}
\hline $\begin{array}{l}\text { Threshold for } \\
\text { the construction } \\
\text { of the network }\end{array}$ & $1 \mathrm{s.d}$ & 1.1 s.d & $1.2 \mathrm{s.d}$ & $1.3 \mathrm{s.d}$ & 1.4 s.d & $1.5 \mathrm{s.d}$ & $1.6 \mathrm{s.d}$ & 1.7 s.d & $1.8 \mathrm{s.d}$ & 1.9 s.d & 2 s.d. \\
\hline First Decile & $\begin{array}{c}-\mathbf{0 . 2 5 7} * * * \\
0.00528\end{array}$ & $\begin{array}{c}-\mathbf{0 . 2 6 1} * * * \\
0.00581\end{array}$ & $\begin{array}{c}-\mathbf{0 . 2 0 6} * * \\
0.0371\end{array}$ & $\begin{array}{c}-\mathbf{0 . 2 4 5} * * \\
0.018\end{array}$ & $\begin{array}{c}-\mathbf{0 . 3 3 0} * * * \\
0.00238\end{array}$ & $\begin{array}{c}-\mathbf{0 . 2 9 0} * * \\
0.0111\end{array}$ & $\begin{array}{c}-\mathbf{0 . 2 9 2} * * \\
0.0139\end{array}$ & $\begin{array}{c}-0.209 \\
0.102\end{array}$ & $\begin{array}{c}-\mathbf{0 . 3 7 2} * * * \\
0.00716\end{array}$ & $\begin{array}{c}-\mathbf{0 . 4 5 1} * * * \\
0.00165\end{array}$ & $\begin{array}{c}-\mathbf{0 . 5 0 7} * * * \\
0.00107\end{array}$ \\
\hline Second Decile & $\begin{array}{c}-\mathbf{0 . 1 7 3} * * \\
0.0378\end{array}$ & $\begin{array}{c}-0.0883 \\
0.305\end{array}$ & $\begin{array}{c}-0.0299 \\
0.739\end{array}$ & $\begin{array}{c}-0.111 \\
0.234\end{array}$ & $\begin{array}{c}-0.149 \\
0.132\end{array}$ & $\begin{array}{c}-0.177 * \\
0.092\end{array}$ & $\begin{array}{c}-0.193 * \\
0.0823\end{array}$ & $\begin{array}{c}-\mathbf{0 . 2 0 6} * \\
0.0762\end{array}$ & $\begin{array}{c}-\mathbf{0 . 2 4 7} * * \\
0.0478\end{array}$ & $\begin{array}{c}-\mathbf{0 . 2 8 9} * * \\
0.0254\end{array}$ & $\begin{array}{c}-0.229 * \\
0.0949\end{array}$ \\
\hline Third Decile & $\begin{array}{c}-\mathbf{0 . 2 7 5} * * * \\
0.00179\end{array}$ & $\begin{array}{c}-\mathbf{0 . 2 3 5} * * \\
0.0103\end{array}$ & $\begin{array}{c}-\mathbf{0 . 2 0 6} * * \\
0.0304\end{array}$ & $\begin{array}{c}-\mathbf{0 . 2 0 7} * * \\
0.0355\end{array}$ & $\begin{array}{c}-\mathbf{0 . 2 0 4} * * \\
0.0486\end{array}$ & $\begin{array}{l}-0.14 \\
0.203\end{array}$ & $\begin{array}{c}-0.156 \\
0.179\end{array}$ & $\begin{array}{c}-0.217 * \\
0.0811\end{array}$ & $\begin{array}{c}-0.181 \\
0.173\end{array}$ & $\begin{array}{c}-\mathbf{0 . 2 9 1} * * \\
0.0359\end{array}$ & $\begin{array}{c}-0.131 \\
0.351\end{array}$ \\
\hline Fourth Decile & $\begin{array}{c}-0.108 \\
0.25\end{array}$ & $\begin{array}{c}-0.0609 \\
0.527\end{array}$ & $\begin{array}{c}-0.039 \\
0.697\end{array}$ & $\begin{array}{c}-0.00912 \\
0.929\end{array}$ & $\begin{array}{c}-0.0222 \\
0.838\end{array}$ & $\begin{array}{c}0.0274 \\
0.812\end{array}$ & $\begin{array}{c}-0.012 \\
0.922\end{array}$ & $\begin{array}{c}-0.0808 \\
0.528\end{array}$ & $\begin{array}{c}0.0426 \\
0.753\end{array}$ & $\begin{array}{c}-0.0471 \\
0.733\end{array}$ & $\begin{array}{c}0.0456 \\
0.753\end{array}$ \\
\hline Fifth Decile & $\begin{array}{c}-0.171 \\
0.134\end{array}$ & $\begin{array}{c}-0.145 \\
0.209\end{array}$ & $\begin{array}{l}-0.14 \\
0.241\end{array}$ & $\begin{array}{l}-0.0943 \\
0.445\end{array}$ & $\begin{array}{c}-0.146 \\
0.272\end{array}$ & $\begin{array}{c}-0.138 \\
0.328\end{array}$ & $\begin{array}{c}-0.112 \\
0.452\end{array}$ & $\begin{array}{c}-0.0978 \\
0.536\end{array}$ & $\begin{array}{c}0.0182 \\
0.913\end{array}$ & $\begin{array}{l}-0.226 \\
0.227\end{array}$ & $\begin{array}{l}-0.244 \\
0.208\end{array}$ \\
\hline Sixth Decile & $\begin{array}{c}-0.0701 \\
0.583\end{array}$ & $\begin{array}{c}-0.018 \\
0.89\end{array}$ & $\begin{array}{c}-0.0612 \\
0.655\end{array}$ & $\begin{array}{l}-0.103 \\
0.477\end{array}$ & $\begin{array}{l}-0.216 \\
0.167\end{array}$ & $\begin{array}{c}-0.296 * \\
0.0882\end{array}$ & $\begin{array}{c}-\mathbf{0 . 3 8 0} * * \\
0.0491\end{array}$ & $\begin{array}{c}-\mathbf{0 . 4 5 6} * * \\
0.0364\end{array}$ & $\begin{array}{c}-0.361 \\
0.121\end{array}$ & $\begin{array}{c}-0.301 \\
0.187\end{array}$ & $\begin{array}{l}-0.18 \\
0.421\end{array}$ \\
\hline Seventh Decile & $\begin{array}{c}-0.0863 \\
0.56\end{array}$ & $\begin{array}{c}-0.0724 \\
0.638\end{array}$ & $\begin{array}{c}-0.0726 \\
0.651\end{array}$ & $\begin{array}{c}-0.0664 \\
0.691\end{array}$ & $\begin{array}{l}-0.208 \\
0.254\end{array}$ & $\begin{array}{c}-0.177 \\
0.349\end{array}$ & $\begin{array}{c}-0.358 \\
0.111\end{array}$ & $\begin{array}{c}-0.242 \\
0.283\end{array}$ & $\begin{array}{c}-0.107 \\
0.65\end{array}$ & $\begin{array}{c}-0.0565 \\
0.81\end{array}$ & $\begin{array}{l}0.047 \\
0.841\end{array}$ \\
\hline Eighth Decile & $\begin{array}{c}-0.314 \\
0.111\end{array}$ & $\begin{array}{c}-0.266 \\
0.188\end{array}$ & $\begin{array}{c}-0.239 \\
0.278\end{array}$ & $\begin{array}{c}-0.249 \\
0.283\end{array}$ & $\begin{array}{l}-0.406 \\
0.111\end{array}$ & $\begin{array}{c}-0.303 \\
0.228\end{array}$ & $\begin{array}{c}-0.594 * \\
0.0762\end{array}$ & $\begin{array}{c}-0.475 \\
0.151\end{array}$ & $\begin{array}{c}-0.379 \\
0.278\end{array}$ & $\begin{array}{c}-0.349 \\
0.31\end{array}$ & $\begin{array}{c}-0.273 \\
0.42\end{array}$ \\
\hline Ninth Decile & $\begin{array}{l}-0.22 \\
0.315\end{array}$ & $\begin{array}{c}-0.2 \\
0.375\end{array}$ & $\begin{array}{c}-0.099 \\
0.658\end{array}$ & $\begin{array}{l}-0.134 \\
0.575\end{array}$ & $\begin{array}{l}-0.183 \\
0.461\end{array}$ & $\begin{array}{c}-0.107 \\
0.671\end{array}$ & $\begin{array}{c}-0.387 \\
0.242\end{array}$ & $\begin{array}{c}-0.285 \\
0.393\end{array}$ & $\begin{array}{c}-0.203 \\
0.583\end{array}$ & $\begin{array}{c}-0.183 \\
0.619\end{array}$ & $\begin{array}{c}-0.103 \\
0.776\end{array}$ \\
\hline $\begin{array}{l}\text { All } \\
\text { transactions }\end{array}$ & $\begin{array}{c}-0.0642 \\
0.761\end{array}$ & $\begin{array}{c}-0.0306 \\
0.889\end{array}$ & $\begin{array}{c}0.0645 \\
0.766\end{array}$ & $\begin{array}{c}0.0327 \\
0.887\end{array}$ & $\begin{array}{c}-0.144 \\
0.568\end{array}$ & $\begin{array}{c}-0.0778 \\
0.763\end{array}$ & $\begin{array}{c}-0.373 \\
0.27\end{array}$ & $\begin{array}{c}-0.276 \\
0.418\end{array}$ & $\begin{array}{c}-0.234 \\
0.533\end{array}$ & $\begin{array}{c}-0.203 \\
0.588\end{array}$ & $\begin{array}{c}-0.124 \\
0.738\end{array}$ \\
\hline
\end{tabular}

FIGURE 1: Estimated coefficients associated with the positive spatial dependence variable in Probit regressions with different thresholds defining the transaction network and different sizes of the IPSA shock used as the dependent variable in the Probit. Each regression controls for the variation of oil prices, dollar prices, VIX index, emerging market index, copper prices, 5-year credit default swaps S\&P 500 stock index, month, and year. The size of the IPSA jump is measured in standard deviations (s.d.).

endogenous heterophily correlate positively with an IPSA jump?

We study the latter question based on the results presented in Figure 2, which are organized in the analogously as in Figure 1. The sole difference between Figures 1 and 2 is that Figure 2 uses the negative spatial dependence indicator as the independent variable in the Probit model. The calculations shown in Figure 2 suggest that heterophily increases the probability of an IPSA jump for the third, fourth, fifth, sixth, and seventh deciles. That is, when brokers with large sold average daily volume, trade with brokers with low sold average daily volume, the probability rises that the IPSA return will increase significantly. In the case of the large volume transaction networks (third and fourth deciles), this relation is consistent with observing a more balanced number of brokers on each side of the market. This condition is to be expected in a more bullish market. This pattern is the opposite of that observed when endogenous homophily occurs. The evidence suggests that this effect becomes more pronounced for larger shocks, especially on the third decile of transactions.

In short, for relatively large transactions (third decile) in which brokers tend towards endogenous heterophily, the likelihood of a positive shock to the IPSA return increases; on the contrary, when brokers tend towards homophily, the probability of an IPSA jump decreases. The latter pattern contradicts the notion suggested by Stoll [23]; transactions between brokers should not affect the return of the capital assets they trade. Moreover, the correlation between the probability of an IPSA jump and endogenous heterophily (or homophily) narrows down the sources of the frictions that affect the assets' returns, as Easley and O'Hara [13] argue.

Linnainmaa and Saar [27] trace these frictions back to how different types of brokers affect equilibrium returns. Thus, to further reduce the potential sources of market return affecting frictions, we study how the exogenous typologies of brokers, considered by the literature $[10,11,19]$, correlate to their matching patterns in the transaction network. That is, we study potential mechanisms associated with exogenous homophily and heterophily, which can explain why this association between endogenous homophily/heterophily and IPSA jumps occurs.

Among all the exogenous typologies considered by the literature, only the possession of a research department emerges as a consistent explanation for the correlation between endogenous homophily (heterophily) and significant increases in the SEE market return measured by the IPSA return. Figures 3(a) and 3(b) show the results for Probit models considering positive spatial dependence of the subnetwork of brokers with a research department (Figure 3(a)) and of the bipartite subnetwork of brokers with and without a research department (Figure $3(\mathrm{~b}))^{26}$ In Figure 3(a), we observe a pattern very similar to that present in Figure 1. That is, endogenous homophily in intraday volume sold between brokers with a research department decreases the probability of occurrence of an IPSA jump. As before, the latter pattern is more apparent for large volume transaction networks (first, second, and third deciles). Additionally, this 
Size of the IPSA jump used in the Probit Regression

\begin{tabular}{|c|c|c|c|c|c|c|c|c|c|c|c|}
\hline $\begin{array}{l}\text { Threshold for } \\
\text { the construction } \\
\text { of the network }\end{array}$ & $1 \mathrm{s.d}$ & $1.1 \mathrm{s.d}$ & $1.2 \mathrm{s.d}$ & $1.3 \mathrm{s.d}$ & 1.4 s.d & 1.5 s.d & 1.6 s.d & 1.7 s.d & $1.8 \mathrm{~s} . \mathrm{d}$ & 1.9 s.d & 2 s.d. \\
\hline \multirow[t]{2}{*}{ First Decile } & -- & -- & -- & -- & -- & -- & -- & -- & -- & -- & -- \\
\hline & -- & -- & -- & -- & -- & -- & -- & -- & -- & -- & -- \\
\hline \multirow{2}{*}{ Second Decile } & -0.108 & -0.371 & -0.275 & -0.155 & -0.0365 & 0.120 & 0.210 & 0.271 & 0.478 & 0.582 & 0.436 \\
\hline & 0.787 & 0.420 & 0.543 & 0.727 & 0.934 & 0.784 & 0.612 & 0.521 & 0.260 & 0.167 & 0.395 \\
\hline Third Decile & $\begin{array}{c}\mathbf{0 . 4 6 1} * * * \\
0.0091\end{array}$ & $\begin{array}{c}\mathbf{0 . 4 4 0} * * \\
0.0134\end{array}$ & $\begin{array}{c}\mathbf{0 . 3 1 1} * * \\
0.0917\end{array}$ & $\begin{array}{c}\mathbf{0 . 4 2 3} * * \\
0.0216\end{array}$ & $\begin{array}{c}\mathbf{0 . 4 7 8} * * \\
0.0115\end{array}$ & $\begin{array}{c}0.553 * * * \\
0.0050\end{array}$ & $\begin{array}{c}\mathbf{0 . 6 5 4} * * * \\
0.0007\end{array}$ & $\begin{array}{c}\mathbf{0 . 6 6 1} * * * \\
0.0011\end{array}$ & $\begin{array}{c}\mathbf{0 . 6 8 2} * * * \\
0.0035\end{array}$ & $\begin{array}{c}\mathbf{0 . 7 6 1} * * * \\
0.0013\end{array}$ & $\begin{array}{c}\mathbf{0 . 8 1 9} * * * \\
0.0007\end{array}$ \\
\hline Fourth Decile & $\begin{array}{c}\mathbf{0 . 3 0 8} * * \\
0.205\end{array}$ & $\begin{array}{l}0.221 \\
0.106\end{array}$ & $\begin{array}{l}0.173 \\
0.225\end{array}$ & $\begin{array}{l}0.232 \\
0.109\end{array}$ & $\begin{array}{l}0.229 \\
0.130\end{array}$ & $\begin{array}{l}0.285 * \\
0.0723\end{array}$ & $\begin{array}{c}\mathbf{0 . 2 7 1} * \\
0.0976\end{array}$ & $\begin{array}{l}0.294 * \\
0.0751 \\
\end{array}$ & $\begin{array}{l}0.318 * \\
0.0903 \\
\end{array}$ & $\begin{array}{c}0.394 * * \\
0.0375\end{array}$ & $\begin{array}{l}0.366 * \\
0.0725 \\
\end{array}$ \\
\hline Fifth Decile & $\begin{array}{c}\mathbf{0 . 2 5 7} * * \\
0.0225\end{array}$ & $\begin{array}{l}\mathbf{0 . 1 9 4} * \\
0.0938\end{array}$ & $\begin{array}{l}0.163 \\
0.170\end{array}$ & $\begin{array}{l}0.158 \\
0.201\end{array}$ & $\begin{array}{l}0.157 \\
0.229\end{array}$ & $\begin{array}{c}0.0574 \\
0.686\end{array}$ & $\begin{array}{c}0.00006 \\
1.000\end{array}$ & $\begin{array}{l}0.101 \\
0.501\end{array}$ & $\begin{array}{l}0.215 \\
0.175\end{array}$ & $\begin{array}{l}0.193 \\
0.230\end{array}$ & $\begin{array}{l}0.222 \\
0.184\end{array}$ \\
\hline Sixth Decile & $\begin{array}{c}\mathbf{0 . 2 6 5} * * * \\
0.0059\end{array}$ & $\begin{array}{c}0.203 * * \\
0.0399\end{array}$ & $\begin{array}{c}\mathbf{0 . 2 1 4} * * \\
0.0364\end{array}$ & $\begin{array}{c}0.257 * * \\
0.0148\end{array}$ & $\begin{array}{c}\mathbf{0 . 2 7 9} * * \\
0.0118\end{array}$ & $\begin{array}{c}0.261 * * \\
0.0270\end{array}$ & $\begin{array}{c}0.258 * * \\
0.0354\end{array}$ & $\begin{array}{c}0.322 * * \\
0.0103\end{array}$ & $\begin{array}{c}0.279 * * \\
0.0492\end{array}$ & $\begin{array}{c}0.347 * * \\
0.0162\end{array}$ & $\begin{array}{c}0.331 * * \\
0.0286\end{array}$ \\
\hline Seventh Decile & $\begin{array}{c}0.218 * * \\
0.0142\end{array}$ & $\begin{array}{c}0.212 * * \\
0.0189\end{array}$ & $\begin{array}{c}0.241 * * \\
0.0101\end{array}$ & $\begin{array}{c}0.248 * * \\
0.0111\end{array}$ & $\begin{array}{c}0.257 * * \\
0.0129\end{array}$ & $\begin{array}{l}0.138 \\
0.206\end{array}$ & $\begin{array}{l}0.101 \\
0.380\end{array}$ & $\begin{array}{c}0.0870 \\
0.476\end{array}$ & $\begin{array}{l}0.115 \\
0.391\end{array}$ & $\begin{array}{l}0.142 \\
0.302\end{array}$ & $\begin{array}{c}0.0369 \\
0.805\end{array}$ \\
\hline \multirow[t]{2}{*}{ Eighth Decile } & 0.134 & 0.0688 & 0.0615 & 0.0611 & 0.0076 & -0.0578 & -0.0503 & -0.0646 & -0.114 & -0.115 & -0.128 \\
\hline & 0.116 & 0.438 & 0.495 & 0.518 & 0.939 & 0.588 & 0.650 & 0.582 & 0.371 & 0.383 & 0.365 \\
\hline \multirow[t]{2}{*}{ Ninth Decile } & 0.111 & 0.115 & 0.127 & 0.0921 & 0.0783 & 0.0597 & 0.0351 & 0.0496 & -0.0320 & -0.0423 & -0.113 \\
\hline & 0.185 & 0.185 & 0.155 & 0.323 & 0.428 & 0.575 & 0.750 & 0.674 & 0.801 & 0.748 & 0.421 \\
\hline $\begin{array}{l}\text { All } \\
\text { transactions }\end{array}$ & $\begin{array}{c}0.216 * * \\
0.120\end{array}$ & $\begin{array}{c}\mathbf{0 . 1 8 5} * * \\
0.0359\end{array}$ & $\begin{array}{c}\mathbf{0 . 2 1 3} * * \\
0.0209\end{array}$ & $\begin{array}{c}\mathbf{0 . 2 2 2} * * \\
0.0222\end{array}$ & $\begin{array}{c}0.275 * * * \\
0.0074\end{array}$ & $\begin{array}{l}\mathbf{0 . 1 9 6 *} \\
0.0710\end{array}$ & $\begin{array}{r}0.223 * \\
0.0528\end{array}$ & $\begin{array}{l}0.205 * \\
0.0958\end{array}$ & $\begin{array}{l}0.223 \\
0.101\end{array}$ & $\begin{array}{l}0.185 \\
0.178\end{array}$ & $\begin{array}{l}0.186 \\
0.207\end{array}$ \\
\hline
\end{tabular}

FIGURE 2: Estimated coefficients associated with the negative spatial dependence variable in Probit regressions with different thresholds defining the transaction network and different sizes of the IPSA shock used as the dependent variable in the Probit. Each regression controls for the variation of oil prices, dollar prices, VIX index, emerging market index, copper prices, 5-year credit default swaps S\&P 500 stock index, month, and year. The size of the IPSA jump is measured in standard deviations (s.d.).

correlation becomes greater in absolute value for larger IPSA jumps. The interpretation of this result is analogous to that provided for the results in Figure 1. The latter implies that the results presented in Figure 3(a) support H2.a.

The results in Figure 3(b) allow us to evaluate the behavior among brokers in different groups. That is, we study the possible effect of endogenous homophily in a network constructed on the basis of exogenous heterophily. Surprisingly, Figure 3(b) shows that, for relatively large transactions (third and fourth deciles) and for IPSA jumps of moderate size (smaller than 1.3 standard deviations), endogenous homophily decreases the probability of an IPSA jump. That is, within the bipartite network, trading with brokers of similar average sold volume decreases the probability that the IPSA return will increase considerably.

To complete the study of the relation between the matching patterns between brokers based on the organization of analysts in a research department and significant increases in the stock market return, now we present the results of the Probit models considering negative spatial dependence. Figure 4(a) presents the relation between endogenous heterophily in the subnetwork of brokers with research department. Analogously to the results presented in Figure 2, in Figure 4(a) clear patterns emerge in large volume transaction networks. First, the correlation between negative spatial dependence and the probability of an IPSA jump tends to increase with the aggregate volume traded by two brokers; and second, the latter correlation increases in absolute value with the intensity of the IPSA jump. Thus, when a heterophilic pattern of matching between brokers emerges is more likely the occurrence of a bull market, even for the subset of traders with research department. Hence, the information contained in Figure 4(a) support H2.b.

On the other hand, Figure 4(b) allows the evaluation of the relation between the likelihood of an IPSA jump when endogenous and exogenous heterophily occurs. Figure 4(b) shows two distinctive patterns. There is some evidence in very large volume transaction networks, and for very significant IPSA jumps, the conjunction of endogenous and exogenous heterophily reduces the probability of an IPSA jump. However, this incipient pattern overwhelmingly reverses when we admit relatively smaller aggregate trades between brokers (fifth trough ninth deciles and all transactions). In other words, in more than a third of the possible combinations of IPSA jumps, and transaction networks, the endogenous heterophily between traders with and without research department may increase the likelihood of a sizeable jump on IPSA return. That is, Figure 4(b) provides evidence that supports H2.c.

The presence of these patterns suggests that having a research department plays a relevant role in the matching process of counterparts in large volume transaction networks on the probability of an IPSA jumps. This regularity is different from the endogenous homophily/heterophily that can be associated, for example, to restrictions imposed by 


\begin{tabular}{|c|c|c|c|c|c|c|c|c|c|c|c|}
\hline \multirow[b]{2}{*}{$\begin{array}{l}\text { Threshold for } \\
\text { the construction } \\
\text { of the network }\end{array}$} & \multicolumn{11}{|c|}{ Size of the IPSA jump used in the Probit Regression } \\
\hline & 1 s.d & 1.1 s.d & $1.2 \mathrm{s.d}$ & $1.3 \mathrm{s.d}$ & 1.4 s.d & $1.5 \mathrm{~s} . \mathrm{d}$ & $1.6 \mathrm{s.d}$ & 1.7 s.d & $1.8 \mathrm{~s} . \mathrm{d}$ & 1.9 s.d & 2 s.d. \\
\hline First Decile & $\begin{array}{c}-\mathbf{0 . 2 5 1} * * * \\
0.00617\end{array}$ & $\begin{array}{c}-0.26 * * * \\
0.00540\end{array}$ & $\begin{array}{c}-\mathbf{0 . 2 1 8} * * \\
0.0276\end{array}$ & $\begin{array}{c}-\mathbf{0 . 2 3 0} * * \\
0.0277\end{array}$ & $\begin{array}{c}-\mathbf{0 . 3 0 6} * * * \\
0.00508\end{array}$ & $\begin{array}{c}-0.243 * * \\
0.0343\end{array}$ & $\begin{array}{c}-0.24 * * \\
0.0374\end{array}$ & $\begin{array}{c}-0.165 \\
0.196\end{array}$ & $\begin{array}{c}-\mathbf{0 . 3 2 9} * * \\
0.0180\end{array}$ & $\begin{array}{c}-\mathbf{0 . 4 0 7} * * * \\
0.00460\end{array}$ & $\begin{array}{c}-\mathbf{0 . 4 5 8} * * * \\
0.00302\end{array}$ \\
\hline Second Decile & $\begin{array}{c}-\mathbf{0 . 2 0 6} * * \\
0.0137\end{array}$ & $\begin{array}{c}-0.124 \\
0.151\end{array}$ & $\begin{array}{c}-0.0571 \\
0.526\end{array}$ & $\begin{array}{l}-0.135 \\
0.149\end{array}$ & $\begin{array}{c}-0.161 \\
0.106\end{array}$ & $\begin{array}{c}-\mathbf{0 . 1 9 5} * \\
0.0645\end{array}$ & $\begin{array}{c}-0.172 \\
0.121\end{array}$ & $\begin{array}{l}-0.187 \\
0.106\end{array}$ & $\begin{array}{c}-\mathbf{0 . 2 3 1} * \\
0.0651\end{array}$ & $\begin{array}{c}-\mathbf{0 . 2 7 4} * * \\
0.0345\end{array}$ & $\begin{array}{c}-0.215 \\
0.118\end{array}$ \\
\hline Third Decile & $\begin{array}{c}-\mathbf{0 . 2 3 5} * * * \\
0.00800\end{array}$ & $\begin{array}{c}-\mathbf{0 . 2 1 4} * * \\
0.0198\end{array}$ & $\begin{array}{c}-0.192 * * \\
0.0433\end{array}$ & $\begin{array}{c}-0.175 * \\
0.0744\end{array}$ & $\begin{array}{c}-\mathbf{0 . 1 9 7 *} \\
0.0575\end{array}$ & $\begin{array}{l}-0.134 \\
0.225\end{array}$ & $\begin{array}{l}-0.150 \\
0.194\end{array}$ & $\begin{array}{c}-0.213 * \\
0.0866\end{array}$ & $\begin{array}{l}-0.178 \\
0.181\end{array}$ & $\begin{array}{c}-\mathbf{0 . 2 8 6} * * \\
0.0383\end{array}$ & $\begin{array}{l}-0.126 \\
0.368\end{array}$ \\
\hline Fourth Decile & $\begin{array}{l}-0.109 \\
0.246\end{array}$ & $\begin{array}{c}-0.0939 \\
0.348\end{array}$ & $\begin{array}{c}-0.0680 \\
0.509\end{array}$ & $\begin{array}{c}-0.0624 \\
0.560\end{array}$ & $\begin{array}{c}-0.0950 \\
0.398\end{array}$ & $\begin{array}{l}-0.0568 \\
0.635\end{array}$ & $\begin{array}{c}-0.0959 \\
0.453\end{array}$ & $\begin{array}{l}-0.168 \\
0.214\end{array}$ & $\begin{array}{l}-0.0513 \\
0.718\end{array}$ & $\begin{array}{l}-0.142 \\
0.328\end{array}$ & $\begin{array}{l}-0.0449 \\
0.765\end{array}$ \\
\hline Fifth Decile & $\begin{array}{c}-0.160 \\
0.156\end{array}$ & $\begin{array}{c}-0.131 \\
0.253\end{array}$ & $\begin{array}{c}-0.123 \\
0.299\end{array}$ & $\begin{array}{c}-0.0745 \\
0.542\end{array}$ & $\begin{array}{c}-0.154 \\
0.245\end{array}$ & $\begin{array}{c}-0.148 \\
0.295\end{array}$ & $\begin{array}{c}-0.119 \\
0.419\end{array}$ & $\begin{array}{c}-0.106 \\
0.501\end{array}$ & $\begin{array}{c}0.00907 \\
0.957\end{array}$ & $\begin{array}{c}-0.233 \\
0.211\end{array}$ & $\begin{array}{c}-0.246 \\
0.204\end{array}$ \\
\hline Sixth Decile & $\begin{array}{c}-0.0951 \\
0.456\end{array}$ & $\begin{array}{c}-0.0419 \\
0.747\end{array}$ & $\begin{array}{c}-0.0514 \\
0.699\end{array}$ & $\begin{array}{c}-0.0939 \\
0.508\end{array}$ & $\begin{array}{c}-0.207 \\
0.178\end{array}$ & $\begin{array}{c}-\mathbf{0 . 2 8 7} * \\
0.0935\end{array}$ & $\begin{array}{c}-\mathbf{0 . 3 6 9} * \\
0.0530\end{array}$ & $\begin{array}{c}-\mathbf{0 . 4 4 4} * * \\
0.0394\end{array}$ & $\begin{array}{c}-0.358 \\
0.125\end{array}$ & $\begin{array}{c}-0.302 \\
0.188\end{array}$ & $\begin{array}{c}-0.185 \\
0.416\end{array}$ \\
\hline Seventh Decile & $\begin{array}{c}-0.0627 \\
0.668\end{array}$ & $\begin{array}{c}-0.0409 \\
0.787\end{array}$ & $\begin{array}{c}-0.0372 \\
0.813\end{array}$ & $\begin{array}{l}-0.0858 \\
0.604\end{array}$ & $\begin{array}{c}-0.225 \\
0.214\end{array}$ & $\begin{array}{c}-0.196 \\
0.297\end{array}$ & $\begin{array}{c}-\mathbf{0 . 3 7 4} * \\
0.0945\end{array}$ & $\begin{array}{c}-0.260 \\
0.246\end{array}$ & $\begin{array}{l}-0.126 \\
0.591\end{array}$ & $\begin{array}{l}-0.0725 \\
0.757\end{array}$ & $\begin{array}{c}0.0357 \\
0.878\end{array}$ \\
\hline Eighth Decile & $\begin{array}{l}-0.302 \\
0.106\end{array}$ & $\begin{array}{l}-0.245 \\
0.202\end{array}$ & $\begin{array}{c}-0.208 \\
0.314\end{array}$ & $\begin{array}{c}-0.306 \\
0.181\end{array}$ & $\begin{array}{c}-\mathbf{0 . 4 5 8} * \\
0.0675\end{array}$ & $\begin{array}{c}-0.353 \\
0.153\end{array}$ & $\begin{array}{c}-0.636 * \\
0.0532\end{array}$ & $\begin{array}{l}-0.520 \\
0.110\end{array}$ & $\begin{array}{l}-0.423 \\
0.217\end{array}$ & $\begin{array}{l}-0.394 \\
0.243\end{array}$ & $\begin{array}{l}-0.320 \\
0.336\end{array}$ \\
\hline Ninth Decile & $\begin{array}{l}-0.220 \\
0.282\end{array}$ & $\begin{array}{l}-0.188 \\
0.368\end{array}$ & $\begin{array}{c}-0.0769 \\
0.712\end{array}$ & $\begin{array}{l}-0.0816 \\
0.714\end{array}$ & $\begin{array}{c}-0.103 \\
0.650\end{array}$ & $\begin{array}{l}-0.0189 \\
0.935\end{array}$ & $\begin{array}{l}-0.445 \\
0.166\end{array}$ & $\begin{array}{l}-0.350 \\
0.281\end{array}$ & $\begin{array}{l}-0.275 \\
0.443\end{array}$ & $\begin{array}{l}-0.255 \\
0.474\end{array}$ & $\begin{array}{l}-0.178 \\
0.614\end{array}$ \\
\hline $\begin{array}{l}\text { All } \\
\text { transactions }\end{array}$ & $\begin{array}{l}-0.0229 \\
0.910\end{array}$ & $\begin{array}{c}0.0172 \\
0.934\end{array}$ & $\begin{array}{l}0.119 \\
0.567\end{array}$ & $\begin{array}{l}0.113 \\
0.605\end{array}$ & $\begin{array}{l}-0.0155 \\
0.947\end{array}$ & $\begin{array}{c}0.0515 \\
0.830\end{array}$ & $\begin{array}{c}-0.399 \\
0.231\end{array}$ & $\begin{array}{c}-0.306 \\
0.363\end{array}$ & $\begin{array}{c}-0.264 \\
0.476\end{array}$ & $\begin{array}{c}-0.237 \\
0.523\end{array}$ & $\begin{array}{r}-0.155 \\
0.672\end{array}$ \\
\hline
\end{tabular}

(a) Estimated coefficients associated with the positive spatial dependence variable in Probit regressions using only the network of traders with research department. The regressions are estimated with different thresholds defining the transaction network and different sizes of the IPSA shock used as the dependent variable in the Probit. Each regression controls for the variation of oil prices, dollar prices, VIX index, emerging market index, copper prices, 5-year credit default swaps S\&P 500 stock index, month, and year. The size of the IPSA jump is measured in standard deviations (s.d.)

\begin{tabular}{|c|c|c|c|c|c|c|c|c|c|c|c|}
\hline \multirow[b]{2}{*}{$\begin{array}{l}\text { Threshold for } \\
\text { the construction } \\
\text { of the network }\end{array}$} & \multicolumn{11}{|c|}{ Size of the IPSA jump used in the Probit Regression } \\
\hline & 1 s.d & $1.1 \mathrm{s.d}$ & $1.2 \mathrm{~s} . \mathrm{d}$ & $1.3 \mathrm{s.d}$ & 1.4 s.d & $1.5 \mathrm{s.d}$ & 1.6 s.d & 1.7 s.d & $1.8 \mathrm{s.d}$ & $1.9 \mathrm{~s} . \mathrm{d}$ & 2 s.d. \\
\hline \multirow[t]{2}{*}{ First Decile } & -0.358 & -0.394 & $-0.476 *$ & -0.374 & -0.265 & -0.114 & -0.445 & $-0.792 * *$ & -0.657 & -0.555 & - \\
\hline & 0.121 & 0.114 & 0.0509 & 0.124 & 0.274 & 0.635 & 0.160 & 0.0484 & 0.116 & 0.186 & - \\
\hline \multirow[t]{2}{*}{ Second Decile } & -0.194 & -0.220 & -0.258 & -0.327 & -0.309 & -0.350 & -0.352 & -0.279 & -0.184 & -0.268 & -0.175 \\
\hline & 0.307 & 0.258 & 0.239 & 0.169 & 0.210 & 0.166 & 0.205 & 0.303 & 0.507 & 0.398 & 0.577 \\
\hline \multirow[t]{2}{*}{ Third Decile } & $-0.415 * *$ & $-0.489 * *$ & $-0.416 *$ & -0.379 & -0.206 & -0.0661 & -0.169 & -0.0488 & -0.117 & -0.235 & -0.420 \\
\hline & 0.0300 & 0.0397 & 0.0845 & 0.125 & 0.382 & 0.778 & 0.532 & 0.851 & 0.679 & 0.456 & 0.249 \\
\hline \multirow[t]{2}{*}{ Fourth Decile } & $-0.353 *$ & -0.376 & $-0.645 * *$ & $-0.513 *$ & -0.385 & -0.227 & -0.144 & -0.225 & -0.594 & -0.573 & -0.493 \\
\hline & 0.0852 & 0.106 & 0.0263 & 0.0747 & 0.187 & 0.438 & 0.611 & 0.507 & 0.151 & 0.168 & 0.244 \\
\hline \multirow[t]{2}{*}{ Fifth Decile } & -0.238 & -0.0959 & -0.191 & -0.164 & -0.0158 & -0.0138 & 0.0547 & -0.0141 & 0.142 & -0.0667 & 0.0105 \\
\hline & 0.291 & 0.672 & 0.459 & 0.543 & 0.953 & 0.961 & 0.845 & 0.964 & 0.660 & 0.853 & 0.978 \\
\hline \multirow[t]{2}{*}{ Sixth Decile } & $-0.488 *$ & -0.297 & -0.657 & -0.502 & -0.347 & -0.552 & -0.489 & - & - & - & - \\
\hline & 0.0962 & 0.316 & 0.116 & 0.216 & 0.383 & 0.276 & 0.337 & - & - & - & - \\
\hline \multirow[t]{2}{*}{ Seventh Decile } & -0.136 & 0.0339 & -0.397 & -0.738 & -0.605 & - & - & - & - & - & - \\
\hline & 0.675 & 0.918 & 0.403 & 0.214 & 0.286 & - & - & - & - & - & - \\
\hline \multirow[t]{2}{*}{ Eighth Decile } & -0.420 & -0.258 & -0.601 & - & - & - & - & - & - & - & - \\
\hline & 0.378 & 0.579 & 0.416 & - & - & - & - & - & - & - & - \\
\hline \multirow[t]{2}{*}{ Ninth Decile } & -0.111 & 0.0598 & 0.172 & - & - & - & - & - & - & - & - \\
\hline & 0.841 & 0.913 & 0.753 & - & - & - & - & - & - & - & - \\
\hline All & - & - & - & - & - & - & - & - & - & - & - \\
\hline transactions & - & - & - & - & - & - & - & - & - & - & - \\
\hline
\end{tabular}

(b) Estimated coefficients associated with the positive spatial dependence variable in Probit regressions using the bipartite network of traders with and without research department. The regressions are estimated with different thresholds defining the transaction network and different sizes of the IPSA shock used as the dependent variable in the Probit. Each regression controls for the variation of oil prices, dollar prices, VIX index, emerging market index, copper prices, 5-year credit default swaps S\&P 500 stock index, month, and year. The size of the IPSA jump is measured in standard deviations (s.d.) 
Size of the IPSA jump used in the Probit Regression

\begin{tabular}{|c|c|c|c|c|c|c|c|c|c|c|c|}
\hline $\begin{array}{l}\text { Threshold for } \\
\text { the construction } \\
\text { of the network }\end{array}$ & 1 s.d & $1.1 \mathrm{s.d}$ & $1.2 \mathrm{s.d}$ & 1.3 s.d & 1.4 s.d & $1.5 \mathrm{s.d}$ & $1.6 \mathrm{s.d}$ & 1.7 s.d & $1.8 \mathrm{s.d}$ & 1.9 s.d & 2 s.d. \\
\hline \multirow[t]{2}{*}{ First Decile } & - & - & - & - & - & - & - & - & - & - & - \\
\hline & - & - & - & - & - & - & - & - & - & - & - \\
\hline \multirow[t]{2}{*}{ Second Decile } & -0.198 & -0.623 & -0.544 & -0.461 & -0.358 & -0.286 & -0.177 & -0.173 & -0.130 & -0.134 & -0.0858 \\
\hline & 0.625 & 0.172 & 0.235 & 0.307 & 0.439 & 0.538 & 0.696 & 0.695 & 0.775 & 0.766 & 0.848 \\
\hline Third Decile & $\begin{array}{c}0.488 * * * \\
0.0063\end{array}$ & $\begin{array}{c}0.598 * * * \\
0.0007\end{array}$ & $\begin{array}{c}0.512 * * * \\
0.0062\end{array}$ & $\begin{array}{c}\mathbf{0 . 5 7 9} * * \\
0.0023\end{array}$ & $\begin{array}{c}\mathbf{0 . 7 0 7} * * * \\
0.0002\end{array}$ & $\begin{array}{c}0.638 * * * \\
0.0020\end{array}$ & $\begin{array}{c}0.714 * * * \\
0.0004\end{array}$ & $\begin{array}{c}\mathbf{0 . 6 4 4} * * * \\
0.0036\end{array}$ & $\begin{array}{c}0.843 * * * \\
0.0002\end{array}$ & $\begin{array}{c}\mathbf{0 . 8 7 6} * * * \\
0.0001\end{array}$ & $\begin{array}{c}0.953 * * * \\
0.00003\end{array}$ \\
\hline Fourth Decile & $\begin{array}{c}\mathbf{0 . 3 0 3} * * \\
0.0438\end{array}$ & $\begin{array}{l}0.245 \\
0.115\end{array}$ & $\begin{array}{l}0.150 \\
0.372\end{array}$ & $\begin{array}{l}0.228 \\
0.185\end{array}$ & $\begin{array}{l}0.232 \\
0.190\end{array}$ & $\begin{array}{l}0.322 * \\
0.0773\end{array}$ & \begin{tabular}{r|}
$0.359 *$ \\
0.0525
\end{tabular} & $\begin{array}{l}\mathbf{0 . 3 5 8 *} \\
0.0660\end{array}$ & $\begin{array}{c}\mathbf{0 . 5 4 8} * * * \\
0.0071\end{array}$ & $\begin{array}{c}\mathbf{0 . 5 9 4} * * * \\
0.0037\end{array}$ & $\begin{array}{c}\mathbf{0 . 7 0 8} * * * \\
0.0006\end{array}$ \\
\hline Fifth Decile & $\begin{array}{c}\mathbf{0 . 2 6 9} * * \\
0.0403\end{array}$ & $\begin{array}{c}\mathbf{0 . 3 0 4} * * \\
0.0210\end{array}$ & $\begin{array}{c}\mathbf{0 . 2 3 6} * * \\
0.0855\end{array}$ & $\begin{array}{l}\mathbf{0 . 2 5 5} * \\
0.0749\end{array}$ & $\begin{array}{c}0.319 * * \\
0.0289\end{array}$ & \begin{tabular}{r|r|}
$0.264 *$ \\
0.0893
\end{tabular} & $\begin{array}{l}0.255 \\
0.115\end{array}$ & $\begin{array}{l}0.290 * \\
0.0798\end{array}$ & $\begin{array}{c}\mathbf{0 . 4 4 2} * * \\
0.0121\end{array}$ & $\begin{array}{c}\mathbf{0 . 4 3 0} * * \\
0.0158\end{array}$ & $\begin{array}{c}\mathbf{0 . 4 5 2} * * \\
0.0142\end{array}$ \\
\hline Sixth Decile & $\begin{array}{c}\mathbf{0 . 2 2 6} * * \\
0.0485\end{array}$ & $\begin{array}{c}0.200 * \\
0.0877\end{array}$ & $\begin{array}{l}\mathbf{0 . 2 1 0} * \\
0.0795\end{array}$ & $\begin{array}{c}\mathbf{0 . 2 2 0} * \\
0.0796\end{array}$ & $\begin{array}{c}0.242 * \\
0.0668\end{array}$ & $\begin{array}{l}0.145 \\
0.306\end{array}$ & $\begin{array}{l}0.167 \\
0.257\end{array}$ & $\begin{array}{l}0.185 \\
0.225\end{array}$ & $\begin{array}{c}0.290 * \\
0.0801\end{array}$ & $\begin{array}{c}0.296 * \\
0.0801\end{array}$ & $\begin{array}{l}0.264 \\
0.141\end{array}$ \\
\hline Seventh Decile & $\begin{array}{c}0.235 * * \\
0.0315\end{array}$ & $\begin{array}{c}0.234 * * \\
0.0331\end{array}$ & $\begin{array}{l}0.207 * \\
0.0671\end{array}$ & $\begin{array}{c}0.235 * * \\
0.0460\end{array}$ & $\begin{array}{c}0.320 * * * \\
0.0089\end{array}$ & $\begin{array}{l}0.153 \\
0.251\end{array}$ & $\begin{array}{l}0.130 \\
0.353\end{array}$ & $\begin{array}{l}0.141 \\
0.323\end{array}$ & $\begin{array}{r}0.259 * \\
0.0962 \\
\end{array}$ & $\begin{array}{l}0.223 \\
0.166\end{array}$ & $\begin{array}{l}0.193 \\
0.254\end{array}$ \\
\hline Eighth Decile & $\begin{array}{c}0.0652 \\
0.540\end{array}$ & $\begin{array}{c}0.0374 \\
0.732\end{array}$ & $\begin{array}{c}0.0491 \\
0.661\end{array}$ & $\begin{array}{l}0.102 \\
0.376\end{array}$ & $\begin{array}{l}0.121 \\
0.323\end{array}$ & $\begin{array}{c}0.0204 \\
0.877\end{array}$ & $\begin{array}{c}0.0465 \\
0.734\end{array}$ & $\begin{array}{c}0.0589 \\
0.675\end{array}$ & $\begin{array}{c}0.0973 \\
0.535\end{array}$ & $\begin{array}{c}0.0724 \\
0.658\end{array}$ & $\begin{array}{c}0.0340 \\
0.847\end{array}$ \\
\hline Ninth Decile & $\begin{array}{c}-0.0982 \\
0.360\end{array}$ & $\begin{array}{c}-0.0487 \\
0.651\end{array}$ & $\begin{array}{c}-0.0224 \\
0.840\end{array}$ & $\begin{array}{c}0.0637 \\
0.578\end{array}$ & $\begin{array}{c}0.0803 \\
0.510\end{array}$ & $\begin{array}{c}-0.0270 \\
0.838\end{array}$ & $\begin{array}{c}-0.483 \\
0.728\end{array}$ & $\begin{array}{c}-0.104 \\
0.467\end{array}$ & $\begin{array}{c}-0.0221 \\
0.886\end{array}$ & $\begin{array}{c}0.0436 \\
0.777\end{array}$ & $\begin{array}{c}-0.0055 \\
0.973\end{array}$ \\
\hline $\begin{array}{l}\text { All } \\
\text { transactions }\end{array}$ & $\begin{array}{c}-0.0410 \\
0.708\end{array}$ & $\begin{array}{c}0.0119 \\
0.914\end{array}$ & $\begin{array}{c}0.0416 \\
0.712\end{array}$ & $\begin{array}{c}0.0817 \\
0.482\end{array}$ & $\begin{array}{c}0.0944 \\
0.444\end{array}$ & $\begin{array}{l}0.104 \\
0.428\end{array}$ & $\begin{array}{l}0.148 \\
0.277\end{array}$ & $\begin{array}{c}0.0340 \\
0.817\end{array}$ & $\begin{array}{c}0.0720 \\
0.661\end{array}$ & $\begin{array}{l}0.158 \\
0.338\end{array}$ & $\begin{array}{l}0.220 \\
0.211\end{array}$ \\
\hline
\end{tabular}

(a) Estimated coefficients associated with the negative spatial dependence variable in Probit regressions using only the network of traders with research department. The regressions are estimated with different thresholds defining the transaction network and different sizes of the IPSA shock used as the dependent variable in the Probit. Each regression controls for the variation of oil prices, dollar prices, VIX index, emerging market index, copper prices, 5 -year credit default swaps S\&P 500 stock index, month, and year. The size of the IPSA jump is measured in standard deviations (s.d.)

Size of the IPSA jump used in the Probit Regression

\begin{tabular}{|c|c|c|c|c|c|c|c|c|c|c|c|}
\hline $\begin{array}{l}\text { Threshold for } \\
\text { the construction } \\
\text { of the network }\end{array}$ & 1 s.d & 1.1 s.d & $1.2 \mathrm{s.d}$ & $1.3 \mathrm{s.d}$ & 1.4 s.d & $1.5 \mathrm{s.d}$ & 1.6 s.d & 1.7 s.d & $1.8 \mathrm{s.d}$ & 1.9 s.d & 2 s.d. \\
\hline \multirow[t]{2}{*}{ First Decile } & -0.163 & -0.108 & -0.109 & -0.239 & -0.325 & -0.312 & $-0.64 * * *$ & $-0.592 * *$ & $-0.445 *$ & $-0.668 * *$ & $-0.480 *$ \\
\hline & 0.351 & 0.54 & 0.542 & 0.218 & 0.123 & 0.166 & 0.00566 & 0.0118 & 0.0638 & 0.0181 & 0.0817 \\
\hline \multirow[t]{2}{*}{ Second Decile } & -0.0117 & -0.0872 & -0.0999 & -0.12 & -0.108 & -0.23 & -0.144 & -0.0439 & 0.0032 & -0.108 & -0.323 \\
\hline & 0.945 & 0.627 & 0.596 & 0.559 & 0.607 & 0.308 & 0.507 & 0.841 & 0.99 & 0.697 & 0.262 \\
\hline \multirow[t]{2}{*}{ Third Decile } & 0.133 & 0.107 & 0.123 & 0.0557 & 0.035 & -0.0368 & -0.0633 & -0.103 & -0.117 & -0.0384 & -0.453 \\
\hline & 0.407 & 0.525 & 0.488 & 0.761 & 0.859 & 0.861 & 0.774 & 0.661 & 0.669 & 0.889 & 0.272 \\
\hline \multirow{2}{*}{ Fourth Decile } & 0.13 & 0.158 & 0.156 & 0.173 & 0.171 & 0.168 & 0.207 & 0.216 & 0.15 & 0.261 & 0.0478 \\
\hline & 0.262 & 0.194 & 0.217 & 0.181 & 0.213 & 0.251 & 0.17 & 0.161 & 0.376 & 0.121 & 0.802 \\
\hline \multirow[t]{2}{*}{ Fifth Decile } & $0.242 *$ & $0.270 *$ & $0.267 *$ & $0.264 *$ & $0.234 *$ & 0.162 & 0.18 & 0.137 & 0.151 & 0.183 & 0.117 \\
\hline & 0.012 & 0.0059 & 0.0086 & 0.0115 & 0.0344 & 0.175 & 0.146 & 0.292 & 0.294 & 0.221 & 0.489 \\
\hline \multirow[t]{2}{*}{ Sixth Decile } & $0.268 *$ & $0.280 *$ & $0.327 *$ & $0.331 *$ & $0.305 *$ & $0.242 *$ & $0.231 * *$ & $0.237 * *$ & 0.13 & 0.12 & 0.107 \\
\hline & 0.0017 & 0.0014 & 0.0003 & 0.0004 & 0.0026 & 0.0263 & 0.0421 & 0.0491 & 0.324 & 0.378 & 0.465 \\
\hline \multirow[t]{2}{*}{ Seventh Decile } & $0.222 *$ & $0.243 *$ & $0.288 *$ & $0.312 *$ & $0.332 *$ & $0.270 *$ & $0.221 *$ & $0.281 * *$ & 0.185 & 0.183 & 0.236 \\
\hline & 0.0093 & 0.0065 & 0.0022 & 0.0015 & 0.0013 & 0.0149 & 0.0554 & 0.0219 & 0.161 & 0.185 & 0.117 \\
\hline \multirow[t]{2}{*}{ Eighth Decile } & 0.113 & 0.118 & 0.149 & 0.152 & $0.199 *$ & 0.138 & 0.181 & $0.224 *$ & 0.0905 & 0.0627 & 0.0872 \\
\hline & 0.192 & 0.199 & 0.115 & 0.121 & 0.0588 & 0.214 & 0.119 & 0.0661 & 0.473 & 0.631 & 0.54 \\
\hline \multirow[t]{2}{*}{ Ninth Decile } & $0.230 *$ & $0.181 *$ & $0.243 *$ & $0.233 *$ & $0.282 *$ & $0.210 *$ & $0.204 *$ & 0.2 & 0.0819 & -0.0007 & 0.0768 \\
\hline & 0.0117 & 0.0566 & 0.0146 & 0.0257 & 0.0107 & 0.0738 & 0.0951 & 0.126 & 0.559 & 0.996 & 0.617 \\
\hline All & $0.202 *$ & 0.13 & 0.166 & $0.279 *$ & $0.371 *$ & $0.311 *$ & $0.310 * *$ & $0.262 *$ & 0.171 & 0.11 & 0.201 \\
\hline transactions & 0.0343 & 0.189 & 0.107 & 0.0128 & 0.0016 & 0.0128 & 0.0173 & 0.0556 & 0.246 & 0.456 & 0.225 \\
\hline
\end{tabular}

(b) Estimated coefficients associated with the negative spatial dependence variable in Probit regressions using the bipartite network of traders with and without research department. The regressions are estimated with different thresholds defining the transaction network and different sizes of the IPSA shock used as the dependent variable in the Probit. Each regression controls for the variation of oil prices, dollar prices, VIX index, emerging market index, copper prices, 5-year credit default swaps S\&P 500 stock index, month, and year. The size of the IPSA jump is measured in standard deviations (s.d.) 
other typologies studied by the literature such as the size of brokers. ${ }^{27}$ The aggregate pattern that emerges from the analysis of Figures 3(a)-4(b) suggests that an informational motive connects matching patterns in the trading network and market returns, as suggested by Hagerty and McDonald [10].

We find no evidence which supports that the proprietary trading activity typology (suggested by Goldstein and others [26]), the investment banking services typology (suggested by Demirbag and others [11]), and the large equity typology (suggested by Hagerty and McDonald [10]) affect the correlation between matching patterns in the trading network and market returns. As a representative example of what happens with the other subnetwork partitions based on alternative typologies, we present below the results analogous to those presented in Figures 3(a) and 3(b) for the typology that divides brokers between those with and those without investment banking services, in Figures 5(a) and 5(b). Appendix shows analogous figures to 5(a) and 5(b) for the other criteria used in the literature to classify brokers exogenously: size, proprietary trading, and nationality. Nonetheless, many of the results we present for the investment banking criterion may be extended to these other classifications. More importantly, the conclusions of these analyses are the same.

In the case of the partition of brokers based on the criterion of providing investment banking services (Figure 5(a)), a similar result is observed as in the case of the subnetwork of brokers with a research department. That is, for relatively large transactions, endogenous homophily correlates with a decrease in the probability of an IPSA jump; however, this correlation is only observed for small jumps (increments of less than 1.5 standard deviations of the IPSA return).

At the same time, it appears that for transactions of intermediate size (deciles 5 and 6), endogenous homophily increases the probability of an IPSA jump. In the absence of a consistent pattern between the correlations presented in Figure 5(a), it is not possible to conjecture what the role of this exogenous characteristic is with respect to the decision made by brokers when it comes time to trade. On the other hand, Figure 5(b) shows the bipartite network results that capture the correlation between the conjunction of endogenous homophily and exogenous heterophily and the IPSA jumps. In this case, significance is only observed in 4 cells. This is interpreted as the presence of noise since no association is observed between spatial dependence with the probability of an IPSA jump in this bipartite network in the vast majority of decile-intensity pairs of the jump. In other words, exogenous homophily or heterophily associated with investment banking does not show a systemic correlation with the market return as a whole.

In conclusion, the evidence suggests that investment banking services is not an appropriate typology to understand the endogenous homophily and heterophily, presented in Figures 1 and 2, and that affects the stock market. These results differ from the analysis that considered the research department typology.

\section{Discussion and Conclusion}

The demutualization process experienced by most of the stock markets of developed and emerging countries in recent years responded to the internationalization of financial markets, regulatory reforms, new financial products, and ultimately, changes in the business environment that made the survival of the stock markets under a mutual structure scheme unfeasible.

This process, accelerated by technological advances, reduced the entry barriers for new participants in the brokerage industry but also compressed the sources of revenue for brokers. In this new environment, it is worth asking about the effects of the demutualization process on the structure of the industry, competition, and, ultimately, the market efficiency levels.

As the market microstructure literature points out, the presence of frictions at the level of brokers has an effect on market efficiency, by affecting the prices of financial assets. Characteristics of brokers, such as their size, financial capabilities, affiliation, and research department, among others, have been mentioned as relevant factors.

Our research shows that there are matching trading patterns among stock brokers that may affect the stock market performance in an emerging market context. First, we present a novel methodology that combines a simple network decomposition and spatial econometrics to study how the exogenous types of the brokers affect their matching choices and the correlation between those matches and the stock market return. Second, we find that considering whether brokers organize their analysts in a research department plays a role in how selling counterparty matches between stock brokers influence the occurrence of a significant increase in the return of a stock market in a developing economy. More precisely, our methodology unveils that when trade tends to occur between brokers with and without research department that have dissimilar intraday average aggregate selling volume, the probability of observing a bull market raises. Simultaneously, we observe that, under the consideration of the research department typology, the presence of endogenous and exogenous homophily reduces the probability of a significant increase of the stock market return. Finally, by studying the Chilean case, we provide evidence of the existence of a relation between homophilic (heterophilic) trading patterns among stock brokers and stock market return. The SSE case provides valuable insights to understand the stock market efficiency in an emerging market context.

Our empirical analysis suggests that brokers' exogenous types, i.e., having a research department, and trading matches may affect the efficiency of the market. As financial literature indicates, prices equal fundamental value in an efficient market. For this, the market is required to be liquid, competitive, and perfect. The latter condition includes absence of frictions and equal access to market prices and information. As our findings suggest the activities of research departments, such as the generation of valuable information about the current and future performance of a company, an industry, or the economic and financial perspective of a country, 


\begin{tabular}{|c|c|c|c|c|c|c|c|c|c|c|c|}
\hline \multirow[b]{2}{*}{$\begin{array}{l}\text { Threshold for } \\
\text { the construction } \\
\text { of the network }\end{array}$} & \multicolumn{11}{|c|}{ Size of the IPSA jump used in the Probit Regression } \\
\hline & 1 s.d & 1.1 s.d & $1.2 \mathrm{s.d}$ & $1.3 \mathrm{s.d}$ & 1.4 s.d & $1.5 \mathrm{s.d}$ & $1.6 \mathrm{~s} . \mathrm{d}$ & 1.7 s.d & $1.8 \mathrm{s.d}$ & 1.9 s.d & 2 s.d. \\
\hline \multirow[t]{2}{*}{ First Decile } & 0.000425 & -0.0795 & -0.0938 & $-0.193 *$ & $-0.234 * *$ & -0.162 & -0.177 & -0.13 & -0.151 & -0.199 & -0.216 \\
\hline & 0.996 & 0.392 & 0.333 & 0.0547 & 0.0263 & 0.148 & 0.129 & 0.29 & 0.262 & 0.152 & 0.146 \\
\hline \multirow{2}{*}{ Second Decile } & $-0.137 *$ & -0.125 & -0.0463 & -0.0979 & -0.0885 & -0.0608 & -0.117 & -0.149 & -0.141 & $-0.209 *$ & -0.129 \\
\hline & 0.0963 & 0.144 & 0.602 & 0.291 & 0.37 & 0.563 & 0.28 & 0.192 & 0.249 & 0.096 & 0.332 \\
\hline \multirow{2}{*}{ Third Decile } & $-0.156 *$ & $-0.162 *$ & $-0.151 *$ & $-0.167 *$ & $-0.169 *$ & -0.0905 & -0.0561 & -0.065 & -0.0952 & -0.0853 & -0.059 \\
\hline & 0.0561 & 0.0543 & 0.0853 & 0.073 & 0.084 & 0.371 & 0.597 & 0.565 & 0.438 & 0.498 & 0.657 \\
\hline \multirow[t]{2}{*}{ Fourth Decile } & 0.0456 & 0.00113 & -0.00476 & -0.0362 & -0.0906 & -0.0373 & -0.00609 & -0.0181 & 0.115 & 0.112 & 0.123 \\
\hline & 0.578 & 0.989 & 0.958 & 0.7 & 0.358 & 0.722 & 0.955 & 0.873 & 0.35 & 0.363 & 0.352 \\
\hline \multirow[t]{2}{*}{ Fifth Decile } & 0.0845 & 0.0234 & 0.0859 & 0.115 & 0.107 & $0.192 *$ & 0.182 & $0.269 * *$ & $0.343 * * *$ & $0.315 * *$ & $0.246 *$ \\
\hline & 0.305 & 0.789 & 0.343 & 0.231 & 0.291 & 0.0757 & 0.105 & 0.0218 & 0.00784 & 0.0175 & 0.0804 \\
\hline \multirow[t]{2}{*}{ Sixth Decile } & $0.167 * *$ & $0.160 *$ & $0.169 *$ & 0.137 & 0.104 & 0.159 & 0.166 & $0.213 *$ & $0.235 *$ & $0.296 * *$ & $0.279 * *$ \\
\hline & 0.044 & 0.0663 & 0.0604 & 0.152 & 0.308 & 0.139 & 0.136 & 0.0646 & 0.0643 & 0.0216 & 0.0461 \\
\hline \multirow[t]{2}{*}{ Seventh Decile } & 0.0924 & 0.108 & 0.0804 & 0.0373 & 0.0132 & 0.0642 & 0.0651 & 0.129 & 0.213 & 0.186 & 0.193 \\
\hline & 0.275 & 0.22 & 0.388 & 0.707 & 0.901 & 0.567 & 0.573 & 0.277 & 0.1 & 0.17 & 0.184 \\
\hline \multirow[t]{2}{*}{ Eighth Decile } & 0.0552 & 0.0734 & 0.061 & 0.0818 & 0.0574 & 0.0855 & 0.00283 & 0.0693 & 0.157 & 0.11 & 0.152 \\
\hline & 0.513 & 0.402 & 0.505 & 0.399 & 0.576 & 0.425 & 0.98 & 0.557 & 0.224 & 0.413 & 0.287 \\
\hline \multirow[t]{2}{*}{ Ninth Decile } & $0.149 *$ & 0.133 & 0.112 & 0.0909 & 0.0118 & 0.0471 & 0.0167 & 0.0871 & $0.229 *$ & $0.237 *$ & $0.277 *$ \\
\hline & 0.0841 & 0.14 & 0.233 & 0.356 & 0.912 & 0.67 & 0.884 & 0.459 & 0.0736 & 0.0757 & 0.0505 \\
\hline All & 0.05 & -0.0207 & -0.0189 & -0.0218 & -0.0286 & 0.0111 & -0.00104 & 0.0812 & 0.113 & 0.214 & $0.275 *$ \\
\hline transactions & 0.576 & 0.827 & 0.846 & 0.833 & 0.794 & 0.923 & 0.993 & 0.516 & 0.413 & 0.115 & 0.0552 \\
\hline
\end{tabular}

(a) Estimated coefficients associated with the positive spatial dependence variable in Probit regressions using only the network of traders with investment banking services. The regressions are estimated with different thresholds defining the transaction network and different sizes of the IPSA shock used as the dependent variable in the Probit. Each regression controls for the variation of oil prices, dollar prices, VIX index, emerging market index, copper prices, 5-year credit default swaps S\&P 500 stock index, month, and year. The size of the IPSA jump is measured in standard deviations (s.d.)

Size of the IPSA jump used in the Probit Regression

\begin{tabular}{|c|c|c|c|c|c|c|c|c|c|c|c|}
\hline $\begin{array}{l}\text { Threshold for } \\
\text { the construction } \\
\text { of the network }\end{array}$ & 1 s.d & 1.1 s.d & $1.2 \mathrm{s.d}$ & $1.3 \mathrm{s.d}$ & 1.4 s.d & 1.5 s.d & 1.6 s.d & 1.7 s.d & 1.8 s.d & 1.9 s.d & 2 s.d. \\
\hline \multirow[t]{2}{*}{ First Decile } & -0.26 & -0.155 & -0.0261 & -0.29 & -0.154 & -0.0188 & -0.0454 & 0.0182 & -0.135 & -0.296 & -0.211 \\
\hline & 0.268 & 0.506 & 0.91 & 0.252 & 0.539 & 0.942 & 0.871 & 0.948 & 0.655 & 0.408 & 0.55 \\
\hline \multirow[t]{2}{*}{ Second Decile } & $-0.402 * *$ & -0.267 & -0.144 & -0.115 & 0.0085 & 0.0489 & 0.0337 & -0.0107 & -0.118 & -0.106 & -0.0319 \\
\hline & 0.0427 & 0.178 & 0.459 & 0.563 & 0.966 & 0.819 & 0.878 & 0.961 & 0.616 & 0.653 & 0.893 \\
\hline \multirow[t]{2}{*}{ Third Decile } & $-0.492 *$ & -0.359 & -0.228 & -0.0938 & 0.0464 & 0.184 & 0.148 & 0.0628 & -0.0212 & -0.00693 & 0.0952 \\
\hline & 0.0526 & 0.158 & 0.359 & 0.702 & 0.851 & 0.465 & 0.567 & 0.817 & 0.946 & 0.983 & 0.771 \\
\hline \multirow[t]{2}{*}{ Fourth Decile } & $-0.600 *$ & -0.469 & -0.585 & -0.453 & -0.345 & -0.19 & -0.0922 & -0.361 & -0.271 & -0.229 & -0.124 \\
\hline & 0.0632 & 0.149 & 0.102 & 0.203 & 0.334 & 0.598 & 0.792 & 0.427 & 0.562 & 0.626 & 0.795 \\
\hline \multirow[t]{2}{*}{ Fifth Decile } & -0.105 & 0.0161 & -0.187 & -0.0705 & 0.059 & 0.23 & 0.294 & 0.00287 & 0.129 & 0.119 & 0.159 \\
\hline & 0.733 & 0.958 & 0.578 & 0.836 & 0.86 & 0.497 & 0.385 & 0.995 & 0.772 & 0.792 & 0.731 \\
\hline \multirow[t]{2}{*}{ Sixth Decile } & 0.251 & 0.368 & 0.272 & 0.34 & 0.198 & 0.329 & 0.166 & -0.144 & -0.132 & -0.12 & -0.0403 \\
\hline & 0.418 & 0.235 & 0.395 & 0.286 & 0.543 & 0.324 & 0.667 & 0.769 & 0.796 & 0.812 & 0.935 \\
\hline \multirow[t]{2}{*}{ Seventh Decile } & 0.0409 & 0.137 & 0.204 & 0.247 & -0.155 & - & -- & -- & -- & -- & -- \\
\hline & 0.931 & 0.772 & 0.66 & 0.589 & 0.767 & 0.891 & & & & & \\
\hline \multirow[t]{2}{*}{ Eighth Decile } & 0.345 & 0.434 & 0.536 & 0.299 & - & - & -- & -- & -- & -- & -- \\
\hline & 0.375 & 0.277 & 0.171 & 0.498 & 0.846 & 0.971 & & & & & \\
\hline \multirow[t]{2}{*}{ Ninth Decile } & 0.528 & 0.633 & 0.715 & 0.748 & 0.266 & 0.306 & -- & -- & -- & -- & -- \\
\hline & 0.285 & 0.203 & 0.146 & 0.125 & 0.635 & 0.597 & & & & & \\
\hline All & 0.65 & 0.762 & $0.877 *$ & 0.563 & 0.103 & 0.164 & -- & -- & -- & -- & -- \\
\hline transactions & 0.189 & 0.125 & 0.0754 & 0.299 & 0.858 & 0.776 & & & & & \\
\hline
\end{tabular}

(b) Estimated coefficients associated with the positive spatial dependence variable in Probit regressions using the bipartite network of traders with and without investment banking services. The regressions are estimated with different thresholds defining the transaction network and different sizes of the IPSA shock used as the dependent variable in the Probit. Each regression controls for the variation of oil prices, dollar prices, VIX index, emerging market index, copper prices, 5-year credit default swaps S\&P 500 stock index, month, and year. The size of the IPSA jump is measured in standard deviations (s.d.) 
may play an important role in the markets' returns. For example, they could help to improve efficiency by reducing the probability of the formation of assets bubbles. At the same time, the coexistence of significant endogenous heterophily in subnetworks constructed under the research department typology and an IPSA jump may indicate that the information generated by the research department enhances the sustainability of the stock market, since they help that prices tend to reflect fundamentals when they deviate from their intrinsic values.

Therefore, from a policy perspective, our study also provides a contribution in evaluating the importance of entry barriers to the brokerage industry and its composition. Thus, from market efficiency perspective, in markets undergoing a demutualization process, there may exist a tradeoff between increasing the number of incumbent brokers and the composition of the brokerage industry. A direct implication of the latter is that having a fixed number of brokers, the greater the proportion of brokers with research department, the better the efficiency in the market. In this sense, it is worth asking what would happen if the market was dominated by brokers without research capabilities? We conjecture that in a context of an emerging economy it may even amplify the impact of these brokers' typologies on the stock market, as the lesser efficiency of financial markets in developing economies suggests [21]. Accordingly, as the level of financial literacy of brokers and customers improves, together with accessible information regarding the brokerage participants in the market, it will let investors to make better-informed elections among different kinds of brokerages services and trade execution practices.

Therefore, our study proposes some directions for extensions. The first obvious extension is to clarify the mechanism that links research departments with stock market returns. A second extension is to improve the understanding of how research departments affect the aggregate stock market's efficiency. One possible conjecture that would explain the latter is that institutional and retail investors usually base their buying/selling decisions on the research emitted by sell-side analysts, reports which help investors to respond to the new information.

\section{Appendix}

See Figures 6, 7, and 8.

\section{Data Availability}

The data used to support the findings of this study are available from the corresponding author upon request.

\section{Conflicts of Interest}

The authors declare that they have no conflicts of interest regarding the publication of this paper.

\section{Acknowledgments}

The authors would like to thank the Santiago Stock Exchange for their help providing the data to elaborate on this research. We also thank an anonymous referee for her comments.

\section{Endnotes}

1. Diamond and Dybvig [4], Allen and Gale [5], Brealey and others [6], and Diamond [7] studied banking in its roles of delegated monitoring, asset transformation, production of information, and reduction of transaction costs. Stracca [8] studies mutual and pension funds in their capacity as delegated portfolio managers by providing asset transformation services, research, administration and custody of securities, portfolio management, and diversification of investment portfolios.

2. A demutualization process consists in the process of reducing the entry barriers to become a stock broker. Namely, the requirement of ownership of a stock market stock is eliminated.

3. The stock market promotes the acquisition and dissemination of information, reducing the transaction costs and facilitating the investment process. Additionally, it reduces agency problems among investors and firms and lessens the cost of capital of issuing companies [30].

4. For instance, suppose the type of a broker is defined by having investment banking services. Then, H2.a tests when brokers with investment banking services and low intraday average selling volume tend to sell to other with investment banking services and low intraday average selling volume, the probability of a large return of the IPSA decreases. On the other hand, hypothesis H2.b tests if brokers with investment banking services and low intraday average selling volume tend to sell to other with investment banking services and high intraday average selling volume, the probability of a large return of the IPSA increases.

5. For interpretation purposes we characterize the brokers' transaction network as a directed network which indicates the volume sold by one broker to another.

6. We follow Eberhard and others [22] in the construction of the transaction network.

7. We construct the same transaction network studied by Eberhard and others [22].

8. Our analysis of the behavior of the broker market is focused on an aggregate level and not on a specific level of certain shares.

9. These attributes are exogenous to the intraday decision to sell a specific volume of stock to a specific counterparty. It is also worth mentioning that we partitioned the set of brokers by using the average of the broker's average equity from 2006 to 2015.

10. Investment banking activities usually refer to issuance of an initial public offering of shares (IPO) and a 


\begin{tabular}{|c|c|c|c|c|c|c|c|c|c|c|c|}
\hline \multirow[b]{2}{*}{$\begin{array}{l}\text { Threshold for } \\
\text { the construction } \\
\text { of the network }\end{array}$} & \multicolumn{11}{|c|}{ Size of the IPSA jump used in the Probit Regression } \\
\hline & 1 s.d & 1.1 s.d & 1.2 s.d & 1.3 s.d & 1.4 s.d & 1.5 s.d & 1.6 s.d & 1.7 s.d & 1.8 s.d & 1.9 s.d & 2 s.d. \\
\hline First Decile & $\begin{array}{c}-0.167 * \\
0.0547\end{array}$ & $\begin{array}{c}-0.157 * \\
0.0819\end{array}$ & $\begin{array}{c}-0.0742 \\
0.436\end{array}$ & $\begin{array}{c}-0.104 \\
0.296\end{array}$ & $\begin{array}{c}-0.205 * \\
0.0507\end{array}$ & $\begin{array}{c}-0.199 * \\
0.0739\end{array}$ & $\begin{array}{c}-0.214 * \\
0.0639\end{array}$ & $\begin{array}{c}-\mathbf{0 . 1 6 9} \\
0.168\end{array}$ & $\begin{array}{c}-\mathbf{0 . 2 9 9} * * \\
0.0262\end{array}$ & $\begin{array}{c}-\mathbf{0 . 3 7 9} * * * \\
0.00650\end{array}$ & $\begin{array}{c}-\mathbf{0 . 2 9 7} * * \\
0.0500\end{array}$ \\
\hline Second Decile & $\begin{array}{c}-\mathbf{0 . 2 5 1} * * * \\
0.00278\end{array}$ & $\begin{array}{c}-0.213 * * \\
0.0140\end{array}$ & $\begin{array}{c}-\mathbf{0 . 1 5 4} * \\
0.0861\end{array}$ & $\begin{array}{c}-0.136 \\
0.152\end{array}$ & $\begin{array}{c}-0.125 \\
0.215\end{array}$ & $\begin{array}{c}-0.129 \\
0.231\end{array}$ & $\begin{array}{c}-0.151 \\
0.181\end{array}$ & $\begin{array}{c}-\mathbf{0 . 2 1 5} * \\
0.0737\end{array}$ & $\begin{array}{c}-\mathbf{0 . 2 5 5} * \\
0.0505\end{array}$ & $\begin{array}{c}-\mathbf{0 . 2 8 4} * * \\
0.0342\end{array}$ & $\begin{array}{c}-0.210 \\
0.136\end{array}$ \\
\hline Third Decile & $\begin{array}{c}-\mathbf{0 . 2 4 7} * * * \\
0.00706\end{array}$ & $\begin{array}{c}-\mathbf{0 . 1 9 0} * * \\
0.0447\end{array}$ & $\begin{array}{c}-0.207 * * \\
0.0354\end{array}$ & $\begin{array}{c}-0.148 \\
0.148\end{array}$ & $\begin{array}{c}-0.170 \\
0.116\end{array}$ & $\begin{array}{c}-0.103 \\
0.370\end{array}$ & $\begin{array}{c}-0.126 \\
0.294\end{array}$ & $\begin{array}{c}-0.220 * \\
0.0920\end{array}$ & $\begin{array}{c}-0.204 \\
0.139\end{array}$ & $\begin{array}{c}-0.236 * \\
0.0947\end{array}$ & $\begin{array}{c}-0.0922 \\
0.520\end{array}$ \\
\hline Fourth Decile & $\begin{array}{c}-\mathbf{0 . 2 0 3} * * \\
0.0478\end{array}$ & $\begin{array}{c}-0.165 \\
0.125\end{array}$ & $\begin{array}{c}-0.117 \\
0.282\end{array}$ & $\begin{array}{c}-0.0649 \\
0.564\end{array}$ & $\begin{array}{c}-0.0363 \\
0.757\end{array}$ & $\begin{array}{c}0.0239 \\
0.846\end{array}$ & $\begin{array}{c}-0.0871 \\
0.515\end{array}$ & $\begin{array}{c}-0.191 \\
0.181\end{array}$ & $\begin{array}{c}-0.0885 \\
0.555\end{array}$ & $\begin{array}{c}-0.145 \\
0.348\end{array}$ & $\begin{array}{c}-0.0106 \\
0.947\end{array}$ \\
\hline Fifth Decile & $\begin{array}{c}-0.273 * * \\
0.0236\end{array}$ & $\begin{array}{c}-\mathbf{0 . 2 1 3} * \\
0.0852\end{array}$ & $\begin{array}{c}-0.165 \\
0.187\end{array}$ & $\begin{array}{l}-0.124 \\
0.327\end{array}$ & $\begin{array}{c}-0.148 \\
0.275\end{array}$ & $\begin{array}{c}-0.0535 \\
0.703\end{array}$ & $\begin{array}{c}-0.125 \\
0.414\end{array}$ & $\begin{array}{l}-0.111 \\
0.492\end{array}$ & $\begin{array}{c}-0.0722 \\
0.678\end{array}$ & $\begin{array}{c}-0.183 \\
0.326\end{array}$ & $\begin{array}{c}-0.204 \\
0.294\end{array}$ \\
\hline Sixth Decile & $\begin{array}{c}-0.0793 \\
0.536\end{array}$ & $\begin{array}{c}-0.0258 \\
0.844\end{array}$ & $\begin{array}{c}-0.0278 \\
0.835\end{array}$ & $\begin{array}{c}0.0947 \\
0.486\end{array}$ & $\begin{array}{c}0.0586 \\
0.685\end{array}$ & $\begin{array}{l}0.142 \\
0.342\end{array}$ & $\begin{array}{c}0.0568 \\
0.728\end{array}$ & $\begin{array}{c}-0.0308 \\
0.862\end{array}$ & $\begin{array}{c}0.0155 \\
0.935\end{array}$ & $\begin{array}{c}-0.0389 \\
0.847\end{array}$ & $\begin{array}{c}-0.0688 \\
0.747\end{array}$ \\
\hline Seventh Decile & $\begin{array}{c}-0.152 \\
0.334\end{array}$ & $\begin{array}{c}-0.168 \\
0.309\end{array}$ & $\begin{array}{c}-0.144 \\
0.376\end{array}$ & $\begin{array}{c}-0.177 \\
0.304\end{array}$ & $\begin{array}{c}-\mathbf{0 . 3 0 8} * \\
0.0990\end{array}$ & $\begin{array}{c}-0.330 * \\
0.0869\end{array}$ & $\begin{array}{c}-\mathbf{0 . 8 8 4} * * * \\
0.000912\end{array}$ & $\begin{array}{c}-\mathbf{0 . 7 7 4} * * * \\
0.00442\end{array}$ & $\begin{array}{c}-\mathbf{0 . 7 2 2} * * \\
0.0107\end{array}$ & $\begin{array}{c}-\mathbf{0 . 6 8 7} * * \\
0.0141\end{array}$ & $\begin{array}{c}-\mathbf{0 . 5 8 4} * * \\
0.0381\end{array}$ \\
\hline Eighth Decile & $\begin{array}{c}-0.213 \\
0.233\end{array}$ & $\begin{array}{c}-0.207 \\
0.282\end{array}$ & $\begin{array}{c}-0.108 \\
0.575\end{array}$ & $\begin{array}{c}-0.185 \\
0.379\end{array}$ & $\begin{array}{c}-0.304 \\
0.178\end{array}$ & $\begin{array}{c}-0.212 \\
0.349\end{array}$ & $\begin{array}{c}-\mathbf{0 . 5 7 8} * \\
0.0831\end{array}$ & $\begin{array}{c}-0.473 \\
0.162\end{array}$ & $\begin{array}{c}-\mathbf{0 . 9 7 1} * * \\
0.0128\end{array}$ & $\begin{array}{c}-\mathbf{0 . 9 3 1} * * \\
0.0149\end{array}$ & $\begin{array}{c}-\mathbf{0 . 8 4 0} * * \\
0.0279\end{array}$ \\
\hline Ninth Decile & $\begin{array}{c}-0.204 \\
0.298\end{array}$ & $\begin{array}{c}-0.167 \\
0.406\end{array}$ & $\begin{array}{c}-0.0581 \\
0.772\end{array}$ & $\begin{array}{c}-0.0656 \\
0.755\end{array}$ & $\begin{array}{c}-0.0805 \\
0.705\end{array}$ & $\begin{array}{c}0.0116 \\
0.957\end{array}$ & $\begin{array}{c}-0.270 \\
0.351\end{array}$ & $\begin{array}{c}-0.410 \\
0.227\end{array}$ & $\begin{array}{c}-0.373 \\
0.310\end{array}$ & $\begin{array}{c}-0.319 \\
0.384\end{array}$ & $\begin{array}{c}-0.239 \\
0.508\end{array}$ \\
\hline $\begin{array}{l}\text { All } \\
\text { transactions }\end{array}$ & $\begin{array}{c}-0.142 \\
0.471\end{array}$ & $\begin{array}{c}-0.0929 \\
0.645\end{array}$ & $\begin{array}{c}0.0207 \\
0.918\end{array}$ & $\begin{array}{c}-0.0774 \\
0.727\end{array}$ & $\begin{array}{c}-0.240 \\
0.332\end{array}$ & $\begin{array}{c}-0.165 \\
0.513\end{array}$ & $\begin{array}{c}-0.445 \\
0.176\end{array}$ & $\begin{array}{c}-0.336 \\
0.311\end{array}$ & $\begin{array}{c}-0.298 \\
0.407\end{array}$ & $\begin{array}{c}-0.231 \\
0.523\end{array}$ & $\begin{array}{c}-0.138 \\
0.701\end{array}$ \\
\hline
\end{tabular}

(a) Estimated coefficients associated with the negative spatial dependence variable in Probit regressions using only the network of traders with proprietary trading activities. The regressions are estimated with different thresholds defining the transaction network and different sizes of the IPSA shock used as the dependent variable in the Probit. Each regression controls for the variation of oil prices, dollar prices, VIX index, emerging market index, copper prices, 5-year credit default swaps S\&P 500 stock index, month, and year. The size of the IPSA jump is measured in standard deviations (s.d.)

Size of the IPSA jump used in the Probit Regression

\begin{tabular}{|c|c|c|c|c|c|c|c|c|c|c|c|}
\hline $\begin{array}{l}\text { Threshold for } \\
\text { the construction } \\
\text { of the network }\end{array}$ & 1 s.d & 1.1 s.d & 1.2 s.d & 1.3 s.d & 1.4 s.d & $1.5 \mathrm{s.d}$ & $1.6 \mathrm{s.d}$ & 1.7 s.d & 1.8 s.d & 1.9 s.d & 2 s.d. \\
\hline \multirow{2}{*}{ First Decile } & -0.107 & -0.379 & -0.284 & -0.178 & -0.322 & -0.585 & -0.450 & -0.378 & -0.346 & -0.298 & -0.229 \\
\hline & 0.665 & 0.220 & 0.354 & 0.562 & 0.339 & 0.152 & 0.261 & 0.343 & 0.378 & 0.446 & 0.549 \\
\hline \multirow[t]{2}{*}{ Second Decile } & -0.0107 & -0.0598 & 0.0454 & 0.104 & 0.0950 & 0.126 & 0.130 & 0.212 & $0.343 *$ & 0.207 & 0.311 \\
\hline & 0.949 & 0.738 & 0.796 & 0.559 & 0.616 & 0.517 & 0.514 & 0.290 & 0.0950 & 0.369 & 0.174 \\
\hline \multirow[t]{2}{*}{ Third Decile } & -0.290 & -0.334 & -0.331 & -0.218 & -0.0947 & -0.0516 & 0.0460 & -0.109 & -0.0298 & -0.148 & -0.317 \\
\hline & 0.123 & 0.100 & 0.110 & 0.292 & 0.648 & 0.815 & 0.833 & 0.675 & 0.914 & 0.632 & 0.343 \\
\hline \multirow[t]{2}{*}{ Fourth Decile } & -0.315 & $-0.428 *$ & $-0.534 * *$ & $-0.507 *$ & -0.351 & -0.211 & -0.0880 & -0.105 & -0.254 & -0.188 & -0.0523 \\
\hline & 0.113 & 0.0626 & 0.0325 & 0.0578 & 0.180 & 0.418 & 0.727 & 0.714 & 0.434 & 0.557 & 0.868 \\
\hline \multirow[t]{2}{*}{ Fifth Decile } & 0.113 & 0.0020 & -0.0956 & 0.0443 & 0.186 & 0.212 & 0.185 & 0.341 & 0.230 & -0.0362 & 0.0623 \\
\hline & 0.592 & 0.993 & 0.710 & 0.862 & 0.469 & 0.442 & 0.527 & 0.251 & 0.487 & 0.917 & 0.861 \\
\hline \multirow[t]{2}{*}{ Sixth Decile } & $-0.712 * *$ & $-0.525 *$ & $-0.693 * *$ & $-0.895 *$ & -0.722 & -1.141 & -0.911 & -0.797 & -0.715 & -0.609 & -0.479 \\
\hline & 0.0145 & 0.0782 & 0.0300 & 0.0704 & 0.106 & 0.149 & 0.183 & 0.205 & 0.283 & 0.323 & 0.403 \\
\hline \multirow[t]{2}{*}{ Seventh Decile } & -0.391 & -0.201 & -0.414 & -0.308 & -0.218 & -0.481 & -0.342 & -0.247 & -0.157 & -0.113 & -0.0393 \\
\hline & 0.216 & 0.536 & 0.247 & 0.388 & 0.543 & 0.293 & 0.458 & 0.586 & 0.744 & 0.818 & 0.936 \\
\hline
\end{tabular}

Eighth Decile

Ninth Decile

All

transactions

(b) Estimated coefficients associated with the negative spatial dependence variable in Probit regressions using the bipartite network of traders with and without proprietary trading activities. The regressions are estimated with different thresholds defining the transaction network and different sizes of the IPSA shock used as the dependent variable in the Probit. Each regression controls for the variation of oil prices, dollar prices, VIX index, emerging market index, copper prices, 5-year credit default swaps S\&P 500 stock index, month, and year. The size of the IPSA jump is measured in standard deviations (s.d.) 


\begin{tabular}{|c|c|c|c|c|c|c|c|c|c|c|c|}
\hline \multirow[b]{2}{*}{$\begin{array}{l}\text { Threshold for } \\
\text { the construction } \\
\text { of the network }\end{array}$} & \multicolumn{11}{|c|}{ Size of the IPSA jump used in the Probit Regression } \\
\hline & 1 s.d & 1.1 s.d & 1.2 s.d & 1.3 s.d & 1.4 s.d & 1.5 s.d & $1.6 \mathrm{s.d}$ & 1.7 s.d & 1.8 s.d & 1.9 s.d & 2 s.d. \\
\hline First Decile & $\begin{array}{c}-0.131 \\
0.134\end{array}$ & $\begin{array}{c}-0.146 \\
0.106\end{array}$ & $\begin{array}{c}-0.135 \\
0.154\end{array}$ & $\begin{array}{c}-\mathbf{0 . 2 4 6} * * \\
0.0121\end{array}$ & $\begin{array}{c}-\mathbf{0 . 2 2 0} * * \\
0.0354\end{array}$ & $\begin{array}{c}-\mathbf{0 . 2 2 2} * * \\
0.0425\end{array}$ & $\begin{array}{c}-0.275 * * \\
0.0142\end{array}$ & $\begin{array}{c}-\mathbf{0 . 2 7 9} * * \\
0.0186\end{array}$ & $\begin{array}{c}-0.342 * * \\
0.0110\end{array}$ & $\begin{array}{c}-0.403 * * * \\
0.00427\end{array}$ & $\begin{array}{c}-\mathbf{0 . 3 2 5} * * \\
0.0317\end{array}$ \\
\hline Second Decile & $\begin{array}{c}-\mathbf{0 . 3 4 2} * * * \\
3.88 \mathrm{e}-05\end{array}$ & $\begin{array}{c}-0.293 * * * \\
0.000613\end{array}$ & $\begin{array}{c}-\mathbf{0 . 2 1 7} * * \\
0.0146\end{array}$ & $\begin{array}{c}-\mathbf{0 . 2 0 2} * * \\
0.0312\end{array}$ & $\begin{array}{c}-0.255 * * \\
0.0116\end{array}$ & $\begin{array}{c}-\mathbf{0 . 2 0 5} * \\
0.0549\end{array}$ & $\begin{array}{c}- \\
0.00727\end{array}$ & $\begin{array}{c}-0.33 * * * \\
0.00455\end{array}$ & $\begin{array}{c}-\mathbf{0 . 2 7 3} * * \\
0.0325\end{array}$ & $\begin{array}{c}-\mathbf{0 . 3 4 0} * * * \\
0.00960\end{array}$ & $\begin{array}{c}-\mathbf{0 . 3 0 3} * * \\
0.0305\end{array}$ \\
\hline Third Decile & $\begin{array}{c}-\mathbf{0 . 2 4 9} * * * \\
0.00509\end{array}$ & $\begin{array}{c}-0.201 * * \\
0.0304\end{array}$ & $\begin{array}{c}-0.150 \\
0.120\end{array}$ & $\begin{array}{c}-0.138 \\
0.168\end{array}$ & $\begin{array}{c}-\mathbf{0 . 1 8 3} * \\
0.0836\end{array}$ & $\begin{array}{c}-0.206 * \\
0.0674\end{array}$ & $\begin{array}{c}-0.222 * \\
0.0634\end{array}$ & $\begin{array}{c}-\mathbf{0 . 2 7 5} * * \\
0.0273\end{array}$ & $\begin{array}{c}-0.235 * \\
0.0767\end{array}$ & $\begin{array}{c}-0.260 * \\
0.0546\end{array}$ & $\begin{array}{c}-0.149 \\
0.288\end{array}$ \\
\hline Fourth Decile & $\begin{array}{c}-0.151 \\
0.101\end{array}$ & $\begin{array}{c}-0.0973 \\
0.312\end{array}$ & $\begin{array}{c}-0.0616 \\
0.531\end{array}$ & $\begin{array}{c}-0.00400 \\
0.969\end{array}$ & $\begin{array}{c}-0.0265 \\
0.805\end{array}$ & $\begin{array}{c}-0.0167 \\
0.884\end{array}$ & $\begin{array}{c}-0.0548 \\
0.648\end{array}$ & $\begin{array}{c}-0.0989 \\
0.436\end{array}$ & $\begin{array}{c}-0.0846 \\
0.532\end{array}$ & $\begin{array}{c}-0.164 \\
0.234\end{array}$ & $\begin{array}{c}-0.0344 \\
0.811\end{array}$ \\
\hline Fifth Decile & $\begin{array}{c}-0.0553 \\
0.572\end{array}$ & $\begin{array}{c}-0.0165 \\
0.869\end{array}$ & $\begin{array}{c}-0.0609 \\
0.556\end{array}$ & $\begin{array}{c}0.0598 \\
0.575\end{array}$ & $\begin{array}{c}0.0772 \\
0.491\end{array}$ & $\begin{array}{c}0.0856 \\
0.469\end{array}$ & $\begin{array}{c}0.0263 \\
0.832\end{array}$ & $\begin{array}{c}-0.0500 \\
0.711\end{array}$ & $\begin{array}{c}-0.105 \\
0.488\end{array}$ & $\begin{array}{c}-0.171 \\
0.273\end{array}$ & $\begin{array}{c}-0.144 \\
0.388\end{array}$ \\
\hline Sixth Decile & $\begin{array}{c}-0.0347 \\
0.728\end{array}$ & $\begin{array}{c}0.00764 \\
0.941\end{array}$ & $\begin{array}{c}-0.0562 \\
0.603\end{array}$ & $\begin{array}{c}0.0216 \\
0.843\end{array}$ & $\begin{array}{c}0.0185 \\
0.873\end{array}$ & $\begin{array}{c}0.0398 \\
0.746\end{array}$ & $\begin{array}{c}-0.00722 \\
0.956\end{array}$ & $\begin{array}{c}-0.100 \\
0.474\end{array}$ & $\begin{array}{c}-0.117 \\
0.448\end{array}$ & $\begin{array}{c}-0.184 \\
0.256\end{array}$ & $\begin{array}{l}-0.139 \\
0.408\end{array}$ \\
\hline Seventh Decile & $\begin{array}{c}-0.161 \\
0.132\end{array}$ & $\begin{array}{c}-0.106 \\
0.340\end{array}$ & $\begin{array}{c}-\mathbf{0 . 2 0 1} * \\
0.0959\end{array}$ & $\begin{array}{c}-0.167 \\
0.178\end{array}$ & $\begin{array}{c}-\mathbf{0 . 2 4 0} * \\
0.0709\end{array}$ & $\begin{array}{c}-0.234 \\
0.102\end{array}$ & $\begin{array}{c}-\mathbf{0 . 3 0 5} * * \\
0.0485\end{array}$ & $\begin{array}{c}-\mathbf{0 . 4 0 2} * * \\
0.0176\end{array}$ & $\begin{array}{c}-\mathbf{0 . 4 4 7} * * \\
0.0140\end{array}$ & $\begin{array}{c}-\mathbf{0 . 3 8 7} * * \\
0.0328\end{array}$ & $\begin{array}{c}-0.275 \\
0.134\end{array}$ \\
\hline Eighth Decile & $\begin{array}{c}-\mathbf{0 . 2 7 2} * * \\
0.0130\end{array}$ & $\begin{array}{c}-0.263 * * \\
0.0291\end{array}$ & $\begin{array}{c}-\mathbf{0 . 2 6 2} * * \\
0.0371\end{array}$ & $\begin{array}{c}-0.163 \\
0.201\end{array}$ & $\begin{array}{c}-\mathbf{0 . 2 7 3} * * \\
0.0490\end{array}$ & $\begin{array}{c}-\mathbf{0 . 3 2 5} * * \\
0.0349\end{array}$ & $\begin{array}{c}-\mathbf{0 . 4 0 6} * * \\
0.0174\end{array}$ & $\begin{array}{c}-0.359 * * \\
0.0427\end{array}$ & $\begin{array}{c}-0.491 * * \\
0.0160\end{array}$ & $\begin{array}{c}-\mathbf{0 . 4 1 9} * * \\
0.0377\end{array}$ & $\begin{array}{l}-0.284 \\
0.157\end{array}$ \\
\hline Ninth Decile & $\begin{array}{c}-\mathbf{0 . 1 7 4} * \\
0.0859\end{array}$ & $\begin{array}{c}-0.124 \\
0.230\end{array}$ & $\begin{array}{c}-\mathbf{0 . 1 7 9} * \\
0.0976\end{array}$ & $\begin{array}{c}-0.130 \\
0.248\end{array}$ & $\begin{array}{c}-0.170 \\
0.164\end{array}$ & $\begin{array}{c}-0.198 \\
0.138\end{array}$ & $\begin{array}{c}-0.293 * * \\
0.0477\end{array}$ & $\begin{array}{c}-\mathbf{0 . 3 0 3} * \\
0.0525\end{array}$ & $\begin{array}{c}-\mathbf{0 . 3 5 5} * * \\
0.0385\end{array}$ & $\begin{array}{c}-\mathbf{0 . 3 0 7} * \\
0.0737\end{array}$ & $\begin{array}{c}-0.248 \\
0.171\end{array}$ \\
\hline $\begin{array}{l}\text { All } \\
\text { transactions }\end{array}$ & $\begin{array}{c}-\mathbf{0 . 1 6 9 *} \\
0.0752\end{array}$ & $\begin{array}{c}-0.122 \\
0.212\end{array}$ & $\begin{array}{c}-0.164 \\
0.109\end{array}$ & $\begin{array}{c}-\mathbf{0 . 2 1 0} * * \\
0.0490\end{array}$ & $\begin{array}{c}-\mathbf{0 . 2 3 3} * * \\
0.0434\end{array}$ & $\begin{array}{c}-\mathbf{0 . 2 0 2} * \\
0.0978\end{array}$ & $\begin{array}{c}-0.209 \\
0.104\end{array}$ & $\begin{array}{c}-0.166 \\
0.212\end{array}$ & $\begin{array}{c}-0.180 \\
0.214\end{array}$ & $\begin{array}{c}-0.204 \\
0.171\end{array}$ & $\begin{array}{c}-0.168 \\
0.287\end{array}$ \\
\hline
\end{tabular}

(a) Estimated coefficients associated with the negative spatial dependence variable in Probit regressions using only the network of traders with large equity. The regressions are estimated with different thresholds defining the transaction network and different sizes of the IPSA shock used as the dependent variable in the Probit. Each regression controls for the variation of oil prices, dollar prices, VIX index, emerging market index, copper prices, 5-year credit default swaps S\&P 500 stock index, month, and year. The size of the IPSA jump is measured in standard deviations (s.d.)

\begin{tabular}{|c|c|c|c|c|c|c|c|c|c|c|c|}
\hline \multirow[b]{2}{*}{$\begin{array}{l}\text { Threshold for } \\
\text { the construction } \\
\text { of the network }\end{array}$} & \multicolumn{11}{|c|}{ Size of the IPSA jump used in the Probit Regression } \\
\hline & 1 s.d & $1.1 \mathrm{s.d}$ & $1.2 \mathrm{s.d}$ & 1.3 s.d & 1.4 s.d & 1.5 s.d & $1.6 \mathrm{s.d}$ & 1.7 s.d & $1.8 \mathrm{~s} . \mathrm{d}$ & 1.9 s.d & 2 s.d. \\
\hline First Decile & $\begin{array}{c}-\mathbf{0 . 4 2 5} * \\
0.0604\end{array}$ & $\begin{array}{c}-0.430 * \\
0.0753\end{array}$ & $\begin{array}{c}-\mathbf{0 . 4 8 8} * \\
0.0536\end{array}$ & $\begin{array}{c}-\mathbf{0 . 5 4 8} * * \\
0.0461\end{array}$ & $\begin{array}{c}-\mathbf{0 . 7 4 3} * * \\
0.0179\end{array}$ & $\begin{array}{c}-\mathbf{0 . 6 4 9} * * \\
0.0388\end{array}$ & $\begin{array}{c}-0.938 * * * \\
0.00851\end{array}$ & $\begin{array}{c}-\mathbf{0 . 8 3 5} * * \\
0.0206\end{array}$ & $\begin{array}{c}-\mathbf{0 . 8 6 2} * * \\
0.0211\end{array}$ & $\begin{array}{c}-0.807 * * \\
0.0284\end{array}$ & $\begin{array}{c}-\mathbf{0 . 7 5 0} * * \\
0.0468\end{array}$ \\
\hline Second Decile & $\begin{array}{c}-0.124 \\
0.473\end{array}$ & $\begin{array}{c}-0.0709 \\
0.692\end{array}$ & $\begin{array}{c}0.0410 \\
0.817\end{array}$ & $\begin{array}{c}0.0479 \\
0.790\end{array}$ & $\begin{array}{c}0.0216 \\
0.912\end{array}$ & $\begin{array}{c}0.0757 \\
0.710\end{array}$ & $\begin{array}{l}0.186 \\
0.357\end{array}$ & $\begin{array}{l}0.181 \\
0.402\end{array}$ & $\begin{array}{c}-0.109 \\
0.677\end{array}$ & $\begin{array}{c}-0.234 \\
0.439\end{array}$ & $\begin{array}{c}-0.112 \\
0.708\end{array}$ \\
\hline Third Decile & $\begin{array}{c}-\mathbf{0 . 4 7 4} * * \\
0.0412\end{array}$ & $\begin{array}{c}-0.359 \\
0.124\end{array}$ & $\begin{array}{c}-0.234 \\
0.300\end{array}$ & $\begin{array}{c}-0.220 \\
0.349\end{array}$ & $\begin{array}{c}-0.244 \\
0.327\end{array}$ & $\begin{array}{c}-0.0998 \\
0.694\end{array}$ & $\begin{array}{c}0.00790 \\
0.975\end{array}$ & $\begin{array}{c}0.0905 \\
0.717\end{array}$ & $\begin{array}{c}0.0599 \\
0.832\end{array}$ & $\begin{array}{l}0.118 \\
0.677\end{array}$ & $\begin{array}{l}0.239 \\
0.409\end{array}$ \\
\hline Fourth Decile & $\begin{array}{l}-0.250 \\
0.349\end{array}$ & $\begin{array}{l}-0.131 \\
0.627\end{array}$ & $\begin{array}{c}-0.00531 \\
0.984\end{array}$ & $\begin{array}{l}0.153 \\
0.561\end{array}$ & $\begin{array}{l}0.121 \\
0.672\end{array}$ & $\begin{array}{l}0.248 \\
0.391\end{array}$ & $\begin{array}{l}0.356 \\
0.208\end{array}$ & $\begin{array}{l}0.469 \\
0.112\end{array}$ & $\begin{array}{c}\mathbf{0 . 6 8 9} * * \\
0.0276\end{array}$ & $\begin{array}{l}0.491 \\
0.110\end{array}$ & $\begin{array}{l}0.436 \\
0.222\end{array}$ \\
\hline Fifth Decile & $\begin{array}{l}0.114 \\
0.711\end{array}$ & $\begin{array}{l}0.224 \\
0.463\end{array}$ & $\begin{array}{l}0.305 \\
0.318\end{array}$ & $\begin{array}{l}0.449 \\
0.153\end{array}$ & $\begin{array}{l}0.590 * \\
0.0660\end{array}$ & $\begin{array}{l}0.261 \\
0.524\end{array}$ & $\begin{array}{l}0.357 \\
0.370\end{array}$ & $\begin{array}{l}0.461 \\
0.260\end{array}$ & $\begin{array}{l}0.609 \\
0.143\end{array}$ & $\begin{array}{l}0.230 \\
0.627\end{array}$ & $\begin{array}{l}0.398 \\
0.384\end{array}$ \\
\hline Sixth Decile & $\begin{array}{c}-0.405 \\
0.409\end{array}$ & $\begin{array}{c}-0.234 \\
0.638\end{array}$ & $\begin{array}{c}-0.153 \\
0.753\end{array}$ & $\begin{array}{c}0.0311 \\
0.950\end{array}$ & $\begin{array}{l}0.195 \\
0.697\end{array}$ & $\begin{array}{l}0.326 \\
0.525\end{array}$ & $\begin{array}{l}0.493 \\
0.328\end{array}$ & $\begin{array}{l}0.547 \\
0.273\end{array}$ & $\begin{array}{l}0.839 \\
0.118\end{array}$ & \begin{tabular}{r|}
$\mathbf{0 . 9 4 9} *$ \\
0.0848 \\
\end{tabular} & $\begin{array}{l}1.128 * \\
0.0454\end{array}$ \\
\hline Seventh Decile & $\begin{array}{l}-0.354 \\
0.473\end{array}$ & $\begin{array}{l}-0.204 \\
0.685\end{array}$ & $\begin{array}{l}-0.124 \\
0.800\end{array}$ & $\begin{array}{c}0.0488 \\
0.924\end{array}$ & $\begin{array}{l}0.200 \\
0.700\end{array}$ & $\begin{array}{l}0.324 \\
0.543\end{array}$ & $\begin{array}{l}0.453 \\
0.400\end{array}$ & $\begin{array}{l}0.512 \\
0.341\end{array}$ & $\begin{array}{l}0.806 \\
0.191\end{array}$ & $\begin{array}{l}0.967 \\
0.116\end{array}$ & $\begin{array}{l}1.214 * \\
0.0691\end{array}$ \\
\hline Eighth Decile & $\begin{array}{c}-0.363 \\
0.492\end{array}$ & $\begin{array}{c}-0.217 \\
0.685\end{array}$ & $\begin{array}{c}-0.108 \\
0.840\end{array}$ & -- & -- & -- & -- & -- & -- & -- & -- \\
\hline Ninth Decile & $\begin{array}{l}0.246 \\
0.536\end{array}$ & $\begin{array}{l}0.371 \\
0.357\end{array}$ & $\begin{array}{l}0.456 \\
0.264\end{array}$ & $\begin{array}{l}0.149 \\
0.775\end{array}$ & $\begin{array}{l}0.266 \\
0.611\end{array}$ & $\begin{array}{l}0.416 \\
0.428\end{array}$ & $\begin{array}{l}0.457 \\
0.377\end{array}$ & $\begin{array}{l}0.566 \\
0.277\end{array}$ & $\begin{array}{l}0.844 \\
0.114\end{array}$ & $\begin{array}{l}0.860 \\
0.104\end{array}$ & $\begin{array}{l}0.917 \\
0.113\end{array}$ \\
\hline $\begin{array}{l}\text { All } \\
\text { transactions }\end{array}$ & $\begin{array}{l}0.408 \\
0.359\end{array}$ & $\begin{array}{l}0.538 \\
0.232\end{array}$ & $\begin{array}{l}0.631 \\
0.166\end{array}$ & $\begin{array}{l}0.291 \\
0.606\end{array}$ & $\begin{array}{l}0.399 \\
0.480\end{array}$ & $\begin{array}{l}0.538 \\
0.337\end{array}$ & $\begin{array}{l}0.586 \\
0.294\end{array}$ & $\begin{array}{l}0.714 \\
0.203\end{array}$ & $\begin{array}{l}1.032 * \\
0.0641\end{array}$ & $\begin{array}{l}1.060 * \\
0.0503\end{array}$ & $\begin{array}{c}1.179 * * \\
0.0477\end{array}$ \\
\hline
\end{tabular}

(b) Estimated coefficients associated with the negative spatial dependence variable in Probit regressions using the bipartite network of traders with and without proprietary trading activities. The regressions are estimated with different thresholds defining the transaction network and different sizes of the IPSA shock used as the dependent variable in the Probit. Each regression controls for the variation of oil prices, dollar prices, VIX index, emerging market index, copper prices, 5-year credit default swaps S\&P 500 stock index, month, and year. The size of the IPSA jump is measured in standard deviations (s.d.) 


\begin{tabular}{|c|c|c|c|c|c|c|c|c|c|c|c|}
\hline \multirow[b]{2}{*}{$\begin{array}{l}\text { Threshold for } \\
\text { the construction } \\
\text { of the network }\end{array}$} & \multicolumn{11}{|c|}{ Size of the IPSA jump used in the Probit Regression } \\
\hline & 1 s.d & $1.1 \mathrm{s.d}$ & 1.2 s.d & $1.3 \mathrm{s.d}$ & 1.4 s.d & 1.5 s.d & $1.6 \mathrm{s.d}$ & 1.7 s.d & 1.8 s.d & 1.9 s.d & 2 s.d. \\
\hline First Decile & $\begin{array}{c}-0.0481 \\
0.607\end{array}$ & $\begin{array}{c}-0.00119 \\
0.990\end{array}$ & $\begin{array}{c}0.00882 \\
0.930\end{array}$ & $\begin{array}{c}-0.0275 \\
0.793\end{array}$ & $\begin{array}{c}-0.0364 \\
0.743\end{array}$ & $\begin{array}{c}-0.0451 \\
0.699\end{array}$ & $\begin{array}{c}-0.0269 \\
0.825\end{array}$ & $\begin{array}{c}-0.0345 \\
0.787\end{array}$ & $\begin{array}{c}-0.0297 \\
0.826\end{array}$ & $\begin{array}{c}-0.0743 \\
0.592\end{array}$ & $\begin{array}{c}-\mathbf{0 . 2 3 5} * \\
0.0966\end{array}$ \\
\hline Second Decile & $\begin{array}{c}-\mathbf{0 . 2 8 8} * * * \\
0.000479\end{array}$ & $\begin{array}{c}-\mathbf{0 . 2 2 8} * * * \\
0.00780\end{array}$ & $\begin{array}{c}-\mathbf{0 . 2 0 8} * * \\
0.0198\end{array}$ & $\begin{array}{c}-\mathbf{0 . 2 1 9} * * \\
0.0190\end{array}$ & $\begin{array}{c}-\mathbf{0 . 2 3 8} * * \\
0.0176\end{array}$ & $\begin{array}{c}-\mathbf{0 . 1 7 8} * \\
0.0943\end{array}$ & $\begin{array}{c}-\mathbf{0 . 2 1 5} * \\
0.0513\end{array}$ & $\begin{array}{c}-0.128 \\
0.274\end{array}$ & $\begin{array}{c}-0.0770 \\
0.543\end{array}$ & $\begin{array}{c}-0.0749 \\
0.569\end{array}$ & $\begin{array}{c}-0.0750 \\
0.573\end{array}$ \\
\hline Third Decile & $\begin{array}{c}-0.0351 \\
0.663\end{array}$ & $\begin{array}{c}-0.0809 \\
0.338\end{array}$ & $\begin{array}{c}-0.0590 \\
0.503\end{array}$ & $\begin{array}{c}-0.137 \\
0.141\end{array}$ & $\begin{array}{c}-0.140 \\
0.149\end{array}$ & $\begin{array}{c}-0.170 \\
0.103\end{array}$ & $\begin{array}{c}-0.114 \\
0.286\end{array}$ & $\begin{array}{c}-0.0876 \\
0.432\end{array}$ & $\begin{array}{c}-0.140 \\
0.252\end{array}$ & $\begin{array}{c}-0.0808 \\
0.522\end{array}$ & $\begin{array}{c}-0.0905 \\
0.491\end{array}$ \\
\hline Fourth Decile & $\begin{array}{c}-0.0424 \\
0.604\end{array}$ & $\begin{array}{c}-0.0586 \\
0.487\end{array}$ & $\begin{array}{c}-0.0866 \\
0.323\end{array}$ & $\begin{array}{c}-0.0910 \\
0.324\end{array}$ & $\begin{array}{c}-0.0891 \\
0.358\end{array}$ & $\begin{array}{c}-0.0953 \\
0.349\end{array}$ & $\begin{array}{c}-0.0292 \\
0.780\end{array}$ & $\begin{array}{c}-0.0170 \\
0.877\end{array}$ & $\begin{array}{c}-0.00998 \\
0.932\end{array}$ & $\begin{array}{c}0.0666 \\
0.584\end{array}$ & $\begin{array}{l}0.163 \\
0.186\end{array}$ \\
\hline Fifth Decile & $\begin{array}{c}-0.0689 \\
0.405\end{array}$ & $\begin{array}{c}-0.0767 \\
0.379\end{array}$ & $\begin{array}{c}-0.0628 \\
0.488\end{array}$ & $\begin{array}{c}-0.0971 \\
0.306\end{array}$ & $\begin{array}{c}-0.110 \\
0.273\end{array}$ & $\begin{array}{c}-0.0993 \\
0.350\end{array}$ & $\begin{array}{c}-0.0467 \\
0.671\end{array}$ & $\begin{array}{c}-0.0305 \\
0.791\end{array}$ & $\begin{array}{c}0.0445 \\
0.724\end{array}$ & $\begin{array}{c}0.00245 \\
0.985\end{array}$ & $\begin{array}{c}-0.0399 \\
0.776\end{array}$ \\
\hline Sixth Decile & $\begin{array}{c}-0.0407 \\
0.631\end{array}$ & $\begin{array}{c}-0.0545 \\
0.533\end{array}$ & $\begin{array}{c}-0.0460 \\
0.611\end{array}$ & $\begin{array}{c}-0.110 \\
0.258\end{array}$ & $\begin{array}{c}-0.0809 \\
0.426\end{array}$ & $\begin{array}{c}-0.0524 \\
0.621\end{array}$ & $\begin{array}{c}-0.0327 \\
0.763\end{array}$ & $\begin{array}{c}0.0374 \\
0.735\end{array}$ & $\begin{array}{c}-0.0555 \\
0.648\end{array}$ & $\begin{array}{c}-0.0471 \\
0.710\end{array}$ & $\begin{array}{c}-0.113 \\
0.398\end{array}$ \\
\hline Seventh Decile & $\begin{array}{c}-0.0598 \\
0.496\end{array}$ & $\begin{array}{c}-0.00673 \\
0.940\end{array}$ & $\begin{array}{l}-0.0737 \\
0.428\end{array}$ & $\begin{array}{c}-0.134 \\
0.178\end{array}$ & $\begin{array}{c}-0.167 \\
0.119\end{array}$ & $\begin{array}{c}- \\
0.0247\end{array}$ & $\begin{array}{c}-\mathbf{0 . 2 4 8} * * \\
0.0433\end{array}$ & $\begin{array}{c}-0.167 \\
0.185\end{array}$ & $\begin{array}{l}-0.101 \\
0.455\end{array}$ & $\begin{array}{c}-0.0316 \\
0.818\end{array}$ & $\begin{array}{c}-0.114 \\
0.431\end{array}$ \\
\hline Eighth Decile & $\begin{array}{c}-0.124 \\
0.180\end{array}$ & $\begin{array}{c}-0.0630 \\
0.508\end{array}$ & $\begin{array}{c}-0.0972 \\
0.334\end{array}$ & $\begin{array}{c}-0.169 \\
0.120\end{array}$ & $\begin{array}{c}-0.165 \\
0.151\end{array}$ & $\begin{array}{c}-0.205 \\
0.103\end{array}$ & $\begin{array}{c}-0.213 \\
0.109\end{array}$ & $\begin{array}{c}-0.214 \\
0.119\end{array}$ & $\begin{array}{c}-0.114 \\
0.434\end{array}$ & $\begin{array}{c}-0.118 \\
0.435\end{array}$ & $\begin{array}{c}-0.153 \\
0.357\end{array}$ \\
\hline Ninth Decile & $\begin{array}{c}-0.0599 \\
0.534\end{array}$ & $\begin{array}{c}-0.00145 \\
0.988\end{array}$ & $\begin{array}{c}0.0190 \\
0.852\end{array}$ & $\begin{array}{c}0.0427 \\
0.690\end{array}$ & $\begin{array}{c}-0.0442 \\
0.705\end{array}$ & $\begin{array}{c}-0.0330 \\
0.790\end{array}$ & $\begin{array}{c}-0.0259 \\
0.841\end{array}$ & $\begin{array}{c}-0.136 \\
0.326\end{array}$ & $\begin{array}{c}-0.0469 \\
0.755\end{array}$ & $\begin{array}{c}-0.0494 \\
0.748\end{array}$ & $\begin{array}{c}-0.159 \\
0.361\end{array}$ \\
\hline $\begin{array}{l}\text { All } \\
\text { transactions }\end{array}$ & $\begin{array}{c}-0.212 * * \\
0.0298\end{array}$ & $\begin{array}{c}-0.165 \\
0.103\end{array}$ & $\begin{array}{c}-0.129 \\
0.214\end{array}$ & $\begin{array}{c}-0.0561 \\
0.602\end{array}$ & $\begin{array}{c}-0.0477 \\
0.681\end{array}$ & $\begin{array}{c}-0.0218 \\
0.858\end{array}$ & $\begin{array}{c}-0.0130 \\
0.919\end{array}$ & $\begin{array}{c}-0.110 \\
0.430\end{array}$ & $\begin{array}{c}-0.0167 \\
0.909\end{array}$ & $\begin{array}{c}-0.0706 \\
0.647\end{array}$ & $\begin{array}{c}-0.129 \\
0.446\end{array}$ \\
\hline
\end{tabular}

(a) Estimated coefficients associated with the negative spatial dependence variable in Probit regressions using only the network of foreign traders. The regressions are estimated with different thresholds defining the transaction network and different sizes of the IPSA shock used as the dependent variable in the Probit. Each regression controls for the variation of oil prices, dollar prices, VIX index, emerging market index, copper prices, 5-year credit default swaps S\&P 500 stock index, month, and year. The size of the IPSA jump is measured in standard deviations (s.d.)

\begin{tabular}{|c|c|c|c|c|c|c|c|c|c|c|c|}
\hline \multirow[b]{2}{*}{$\begin{array}{l}\text { Threshold for } \\
\text { the construction } \\
\text { of the network }\end{array}$} & \multicolumn{11}{|c|}{ Size of the IPSA jump used in the Probit Regression } \\
\hline & 1 s.d & $1.1 \mathrm{s.d}$ & 1.2 s.d & 1.3 s.d & 1.4 s.d & $1.5 \mathrm{s.d}$ & 1.6 s.d & 1.7 s.d & 1.8 s.d & 1.9 s.d & 2 s.d. \\
\hline \multirow[t]{2}{*}{ First Decile } & - & - & - & - & - & - & - & - & - & - & - \\
\hline & - & - & - & - & - & - & - & - & - & - & - \\
\hline Second Decile & $\begin{array}{c}-0.0367 \\
0.793\end{array}$ & $\begin{array}{c}0.0956 \\
0.498\end{array}$ & $\begin{array}{l}0.210 \\
0.134\end{array}$ & $\begin{array}{l}0.272 * \\
0.0590\end{array}$ & $\begin{array}{l}0.279 * \\
0.0675\end{array}$ & $\begin{array}{c}0.315 * * \\
0.0489\end{array}$ & $\begin{array}{l}0.303 * \\
0.0712\end{array}$ & $\begin{array}{l}0.344 * \\
0.0502\end{array}$ & $\begin{array}{l}0.266 \\
0.176\end{array}$ & $\begin{array}{l}0.336 * \\
0.0889\end{array}$ & $\begin{array}{c}0.345 * \\
0.0956\end{array}$ \\
\hline Third Decile & $\begin{array}{c}-\mathbf{0 . 4 9 9} * * \\
0.0256\end{array}$ & $\begin{array}{c}-0.369 * \\
0.0999\end{array}$ & $\begin{array}{c}-0.281 \\
0.204\end{array}$ & $\begin{array}{c}-0.134 \\
0.544\end{array}$ & $\begin{array}{c}-0.297 \\
0.218\end{array}$ & $\begin{array}{c}-0.295 \\
0.271\end{array}$ & $\begin{array}{c}-0.221 \\
0.408\end{array}$ & $\begin{array}{c}-0.154 \\
0.562\end{array}$ & $\begin{array}{l}-0.257 \\
0.413\end{array}$ & $\begin{array}{r}-0.207 \\
0.517\end{array}$ & $\begin{array}{c}-0.143 \\
0.661\end{array}$ \\
\hline Fourth Decile & $\begin{array}{c}-0.289 \\
0.188\end{array}$ & $\begin{array}{c}-0.227 \\
0.338\end{array}$ & $\begin{array}{c}-0.255 \\
0.305\end{array}$ & $\begin{array}{c}-0.0766 \\
0.757\end{array}$ & $\begin{array}{c}-0.0928 \\
0.718\end{array}$ & $\begin{array}{c}-0.104 \\
0.714\end{array}$ & $\begin{array}{c}-0.0218 \\
0.939\end{array}$ & $\begin{array}{c}0.0670 \\
0.814\end{array}$ & $\begin{array}{c}-0.00826 \\
0.980\end{array}$ & $\begin{array}{c}0.0658 \\
0.843\end{array}$ & $\begin{array}{l}0.174 \\
0.604\end{array}$ \\
\hline Fifth Decile & $\begin{array}{c}-0.149 \\
0.553\end{array}$ & $\begin{array}{c}-0.145 \\
0.597\end{array}$ & $\begin{array}{c}-0.0356 \\
0.894\end{array}$ & $\begin{array}{c}-0.0479 \\
0.864\end{array}$ & $\begin{array}{c}-0.147 \\
0.615\end{array}$ & $\begin{array}{c}-0.208 \\
0.541\end{array}$ & $\begin{array}{c}-0.134 \\
0.693\end{array}$ & $\begin{array}{c}-0.388 \\
0.383\end{array}$ & $\begin{array}{c}-0.296 \\
0.519\end{array}$ & $\begin{array}{r}-0.267 \\
0.568\end{array}$ & $\begin{array}{c}-0.215 \\
0.650\end{array}$ \\
\hline Sixth Decile & $\begin{array}{c}\mathbf{0 . 4 7 7} * * \\
0.0447\end{array}$ & $\begin{array}{l}0.370 \\
0.178\end{array}$ & $\begin{array}{l}\mathbf{0 . 4 8 9 *} \\
0.0637\end{array}$ & $\begin{array}{l}0.332 \\
0.229\end{array}$ & $\begin{array}{l}0.237 \\
0.396\end{array}$ & $\begin{array}{l}0.187 \\
0.554\end{array}$ & $\begin{array}{l}0.256 \\
0.420\end{array}$ & $\begin{array}{l}0.116 \\
0.743\end{array}$ & $\begin{array}{l}0.280 \\
0.436\end{array}$ & $\begin{array}{l}0.329 \\
0.357\end{array}$ & $\begin{array}{l}0.453 \\
0.224\end{array}$ \\
\hline Seventh Decile & $\begin{array}{c}-0.662 \\
0.160\end{array}$ & $\begin{array}{c}-0.483 \\
0.321\end{array}$ & $\begin{array}{c}-0.387 \\
0.424\end{array}$ & $\begin{array}{c}-0.248 \\
0.603\end{array}$ & $\begin{array}{c}-0.143 \\
0.766\end{array}$ & $\begin{array}{l}- \\
-\end{array}$ & $\begin{array}{l}- \\
-\end{array}$ & $\begin{array}{l}- \\
-\end{array}$ & $\begin{array}{l}- \\
-\end{array}$ & $\begin{array}{l}- \\
-\end{array}$ & $\begin{array}{l}- \\
-\end{array}$ \\
\hline Eighth Decile & - & - & $\begin{array}{l}- \\
-\end{array}$ & - & $\begin{array}{l}- \\
-\end{array}$ & - & - & - & - & - & $\begin{array}{l}- \\
-\end{array}$ \\
\hline Ninth Decile & $\begin{array}{c}-0.354 \\
0.476\end{array}$ & $\begin{array}{c}-0.215 \\
0.677\end{array}$ & $\begin{array}{c}-0.108 \\
0.833\end{array}$ & $\begin{array}{c}0.0605 \\
0.903\end{array}$ & $\begin{array}{l}0.130 \\
0.795\end{array}$ & - & - & - & - & - & - \\
\hline All & - & - & - & - & - & - & - & - & - & - & - \\
\hline transactions & - & & - & - & - & - & - & - & - & - & - \\
\hline
\end{tabular}

(b) Estimated coefficients associated with the negative spatial dependence variable in Probit regressions using the bipartite network of traders with and without proprietary trading activities. The regressions are estimated with different thresholds defining the transaction network and different sizes of the IPSA shock used as the dependent variable in the Probit. Each regression controls for the variation of oil prices, dollar prices, VIX index, emerging market index, copper prices, 5-year credit default swaps S\&P 500 stock index, month, and year. The size of the IPSA jump is measured in standard deviations (s.d.) 
seasoned equity offering (SEO), debt securities, mergers and acquisitions (M\&A), and financial advice [31].

11. The latter trend also generates a source of conflict of interest because brokers' proprietary trading activities conflict with their fiduciary responsibility to obtain "best execution" and "independent" trades for clients.

12. A link between two brokers indicates the total volume sold by one broker to the other above a threshold. See Eberhard and others [22] for a detailed description on how to construct the broker's transaction network.

13. As mentioned in the financial literature, in Chile as in other markets, technological changes, competition, the emergence of professional investors, and the need to establish long-term relationships with customers have generated a concentrated market with a pyramidal type structure, consequently, affecting the brokerage services offered by brokers. Following Goldstein and others [26], there are also full-service and low-cost brokers in Chile. The former offers a full range of high-cost and highquality brokerage services, while the latter focuses on the execution of low-cost purchase/sale transactions.

14. A criterium generates a partition of the set of brokers into two disjoint sets of brokers, a set of brokers that meet the criterium to be categorized as type " $\mathrm{A}$ " and a set of brokers that do not meet the criterium to be labeled as type "A".

15. We follow the same definitions for the network objects as in Eberhard and others [22]. If link ij exists in the transaction subnetwork $g^{A}$, then ij does not exist in $g^{B}$.

16. The calculation for the standard deviation of the IPSA return is made considering the last 360 days; that is, we use a "moving year."

17. Eberhard and others [22] find that the structure of transaction network between brokers correlates only with IPSA jumps and not with significant drops in this indicator.

18. We compared the average equity of each broker from 2006 to 2015 with respect to the entire industry average in the same period.

19. For example, the brokers' transaction subnetwork with a research department, the brokers' transaction subnetwork without a research department, or the bipartite subnetwork between both types of brokers.

20. Studying spatial dependence within respective groups allows us to analyze whether the choice of selling to a specific broker is just an endogenous choice to the financial market or if it is also a choice associated with the intermediaries' own characteristics

21. Thus, a statistically significant coefficient on the spatial dependency indicator in the subnetworks provides valuable information about the mechanism that would explain the presence of homophily/heterophily in the entire daily transaction network.

22. The interested reader can request the tests for spatial dependency (positive and negative) to the authors.
23. All analogous results for negative spatial dependence are available upon request.

24. Additionally, the standard nomenclature is included, where ${ }^{*},{ }^{* *}$, and ${ }^{* * *}$ represent significance at $10 \%, 5 \%$, and $1 \%$, respectively, and the coefficients are in bold font.

25. We consider the transaction networks built considering the first, second, third, and fourth deciles of the aggregate traded volume between two brokers as large volume transaction networks.

26. There are no testable hypotheses for the subnetwork of brokers with type "no-A", however the results of those analysis are available upon request.

27. The analogous figures for all the subnetworks based on the exogenous criteria mentioned in this paper (size, investment banking services, and proprietary trading) are also available upon request.

\section{References}

[1] F. Allen, "Do financial institutions matter?" Journal of Finance, vol. 56, no. 4, pp. 1165-1175, 2001.

[2] A. Sensoy and B. M. Tabak, "Dynamic spanning trees in stock market networks: the case of Asia-Pacific," Physica A: Statistical Mechanics and its Applications, vol. 414, pp. 387-402, 2014.

[3] S. M. Guerra, T. C. Silva, B. M. Tabak, R. A. de Souza Penaloza, and R. C. de Castro Miranda, "Systemic risk measures," Physica A: Statistical Mechanics and its Applications, vol. 442, Article ID 16392, pp. 329-342, 2016.

[4] D. W. Diamond and P. H. Dybvig, "Bank runs, deposit insurance, and liquidity," Journal of Political Economy, vol. 91, no. 3, pp. 401-419, 1983.

[5] F. Allen and D. Gale, "Financial markets, intermediaries, and intertemporal smoothing," Journal of Political Economy, vol. 105, no. 3, pp. 523-546, 1997.

[6] R. Brealey, H. E. Leland, and D. H. Pyle, "Informational asymmetries, financial structure, and financial intermediation," The Journal of Finance, vol. 32, no. 2, pp. 371-387, 1977.

[7] D. W. Diamond, "Financial intermediation and delegated monitoring," The Review of Economic Studies, vol. 51, no. 3, pp. 393414, 1984.

[8] L. Stracca, "Delegated portfolio management: a survey of the theoretical literature," Journal of Economic Surveys, vol. 20, no. 5, pp. 823-848, 2006.

[9] N. Hardy, N. S. Magner, J. Lavin, R. A. Cardenas, and M. JaraBertin, "Small consequences of a major agreement: the MILA case," Academia Revista Latinoamericana de Administración, vol. 31, no. 3, pp. 486-518, 2018.

[10] K. Hagerty and R. McDonald, "Brokerage, market fragmentation, and securities market regulation," in The Industrial Organization and Regulation of the Securities Industry, pp. 3562, University of Chicago Press, 1996.

[11] M. Demirbag, M. McGuinness, A. Akin, N. Bayyurt, and E. Basti, "The professional service firm (PSF) in a globalised economy: A study of the efficiency of securities firms in an emerging market," International Business Review, vol. 25, no. 5, pp. 1089-1102, 2016.

[12] D. Lee, J. Kim, and H. Kang, "Do larger brokerage firms enjoy larger economies of scale and scope?" Seoul Journal of Economics, vol. 27, pp. 445-467, 2014. 
[13] D. Easley and M. O'Hara, "Microstructure and asset pricing," Handbook of the Economics of Finance, vol. 1, pp. 1021-1051, 2003.

[14] L. Blume, D. Easley, and M. O'hara, "Market statistics and technical analysis: the role of volume," The Journal of Finance, vol. 49, no. 1, pp. 153-181, 1994.

[15] J. Y. Campbell, S. J. Grossman, and J. Wang, “Trading volume and serial correlation in stock returns," The Quarterly Journal of Economics, vol. 108, no. 4, pp. 905-939, 1993.

[16] C. M. C. Lee and B. Swaminathan, "Price momentum and trading volume," Journal of Finance, vol. 55, no. 5, pp. 2017-2069, 2000.

[17] M. McPherson, L. Smith-Lovin, and J. M. Cook, "Birds of a feather: homophily in social networks," Annual Review of Sociology, vol. 27, pp. 415-444, 2001.

[18] L. Anselin, Spatial Econometrics: Methods and Models, Kluwer Academic Publishers, Dordrecht, Nederlands, 2001.

[19] H. S. Choi, J. Clarke, S. P. Ferris, and N. Jayaraman, "The effects of regulation on industry structure and trade generation in the US securities industry," Journal of Banking \& Finance, vol. 33, no. 8, pp. 1434-1445, 2009.

[20] S. Liu, "Commission deregulation and performance of securities firms: Further evidence from Japan," Journal of Economics and Business, vol. 60, no. 4, pp. 355-368, 2008.

[21] C. Kearney, "Emerging markets research: Trends, issues and future directions," Emerging Markets Review, vol. 13, no. 2, pp. 159-183, 2012.

[22] J. Eberhard, J. F. Lavin, and A. Montecinos-Pearce, "A networkbased dynamic analysis in an equity stock market," Complexity, vol. 2017, Article ID 3979836, 16 pages, 2017.

[23] H. R. Stoll, "Market microstructure," Handbook of the Economics of Finance, vol. 1, pp. 553-604, 2003.

[24] J. Hasbrouck and G. Saar, "Low-latency trading," Journal of Financial Markets, vol. 16, no. 4, pp. 646-679, 2013.

[25] E. Boehmer, R. Jennings, and L. Wei, "Public disclosure and private decisions: equity market execution quality and order routing," Review of Financial Studies, vol. 20, no. 2, pp. 315-358, 2007.

[26] M. A. Goldstein, P. Irvine, E. Kandel, and Z. Wiener, "Brokerage commissions and institutional trading patterns," Review of Financial Studies, vol. 22, no. 12, pp. 5175-5212, 2009.

[27] J. T. Linnainmaa and G. Saar, "Lack of anonymity and the inference from order flow," Review of Financial Studies, vol. 25, no. 5, pp. 1414-1456, 2012.

[28] S. Hayes, A. Spence, and D. Marks, Competition in the Investment Banking Industry, Harvard University Press, 1983.

[29] B. N. Anand and A. Galetovic, "Relationships, competition and the structure of investment banking markets," The Journal of Industrial Economics, vol. 54, no. 2, pp. 151-199, 2006.

[30] P. Arestis, P. O. Demetriades, and K. B. Luintel, "Financial development and economic growth: the role of stock markets," Journal of Money, Credit and Banking, vol. 33, no. 1, pp. 16-41, 2001.

[31] J. R. Ritter, "Investment banking and securities issuance," Handbook of the Economics of Finance, vol. 1, pp. 255-306, 2003. 


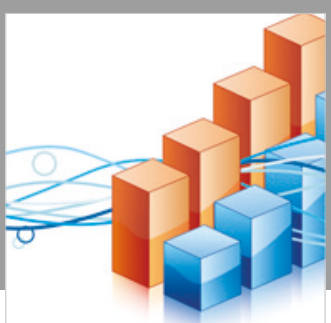

Advances in

Operations Research

\section{-n-m}
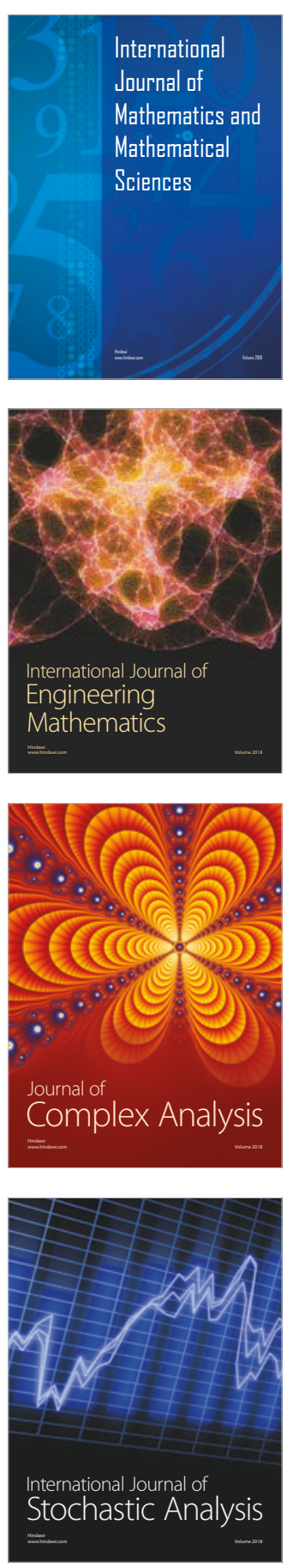
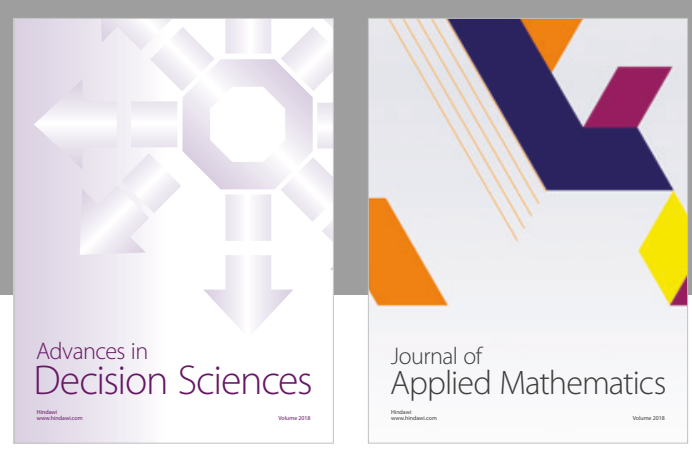

Journal of

Applied Mathematics
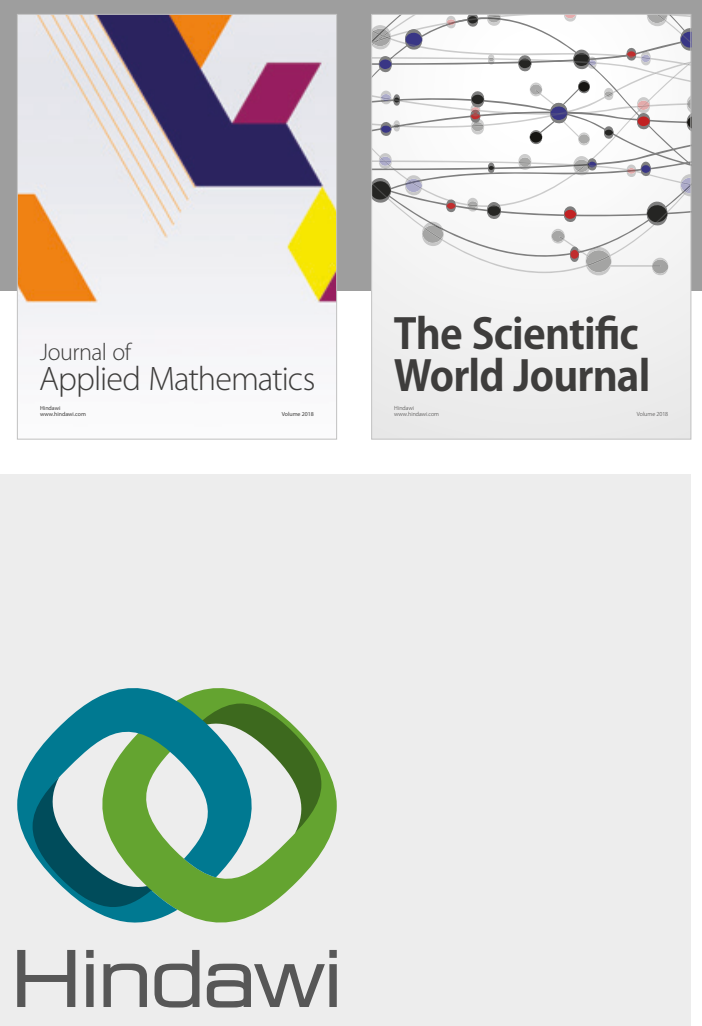

Submit your manuscripts at

www.hindawi.com

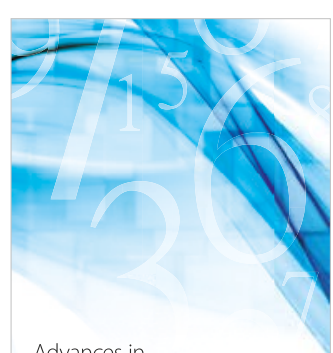

Advances in
Numerical Analysis
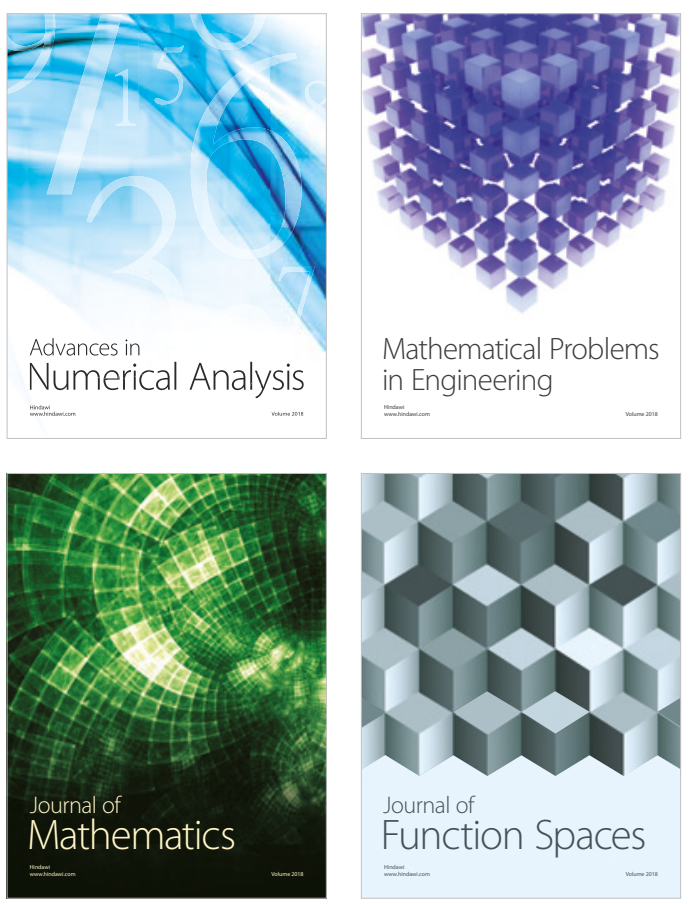

Mathematical Problems in Engineering

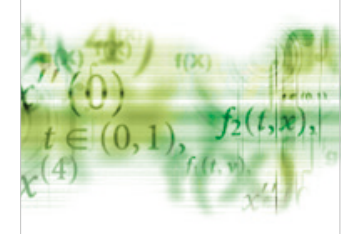

International Journal of

Differential Equations

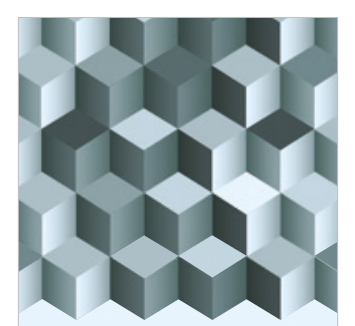

Journal of

Function Spaces
The Scientific

World Journal

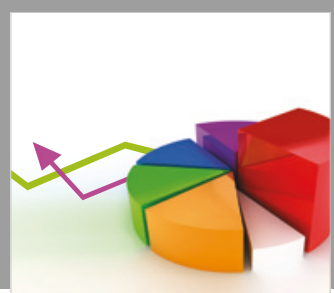

Journal of

Probability and Statistics
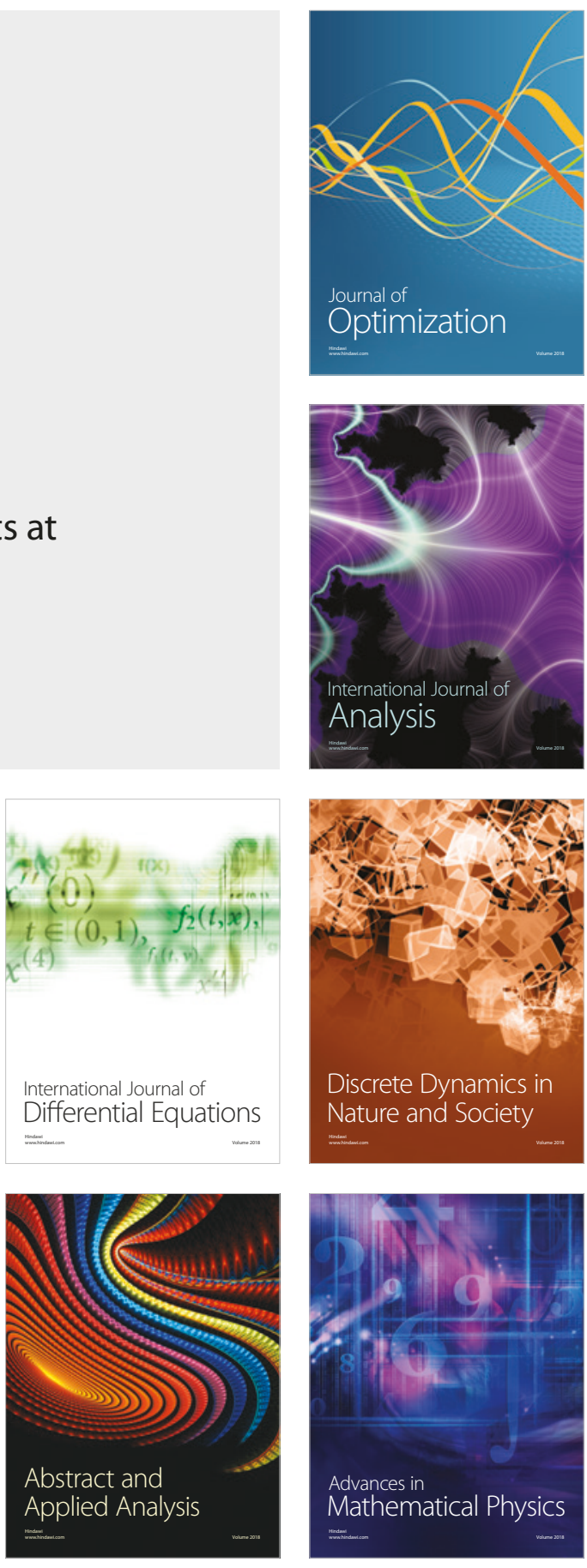